\title{
A Novel Approach for the Direct Determination of 28 Analytes in a Ce Matrix Without Chemical Separation Using CCD Detector-based ICP-AES
}

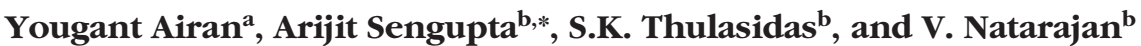 \\ a Chemistry Department, Hindu College, University of Delhi, Delhi, India \\ b Radiochemistry Division, Bhabha Atomic Research Centre, Trombay, Mumbai, India
}

\section{INTRODUCTION}

Inductively coupled plasma (ICP) has been employed as a source for atomic emission spectrometry (AES) for over a decade (1-2). Owing to its capability of determining lower concentrations in a wide range of materials (3-4) and the advantages of being a sensitive method with a long dynamic range, it is clearly an excellent method for rapid multi-element analysis (5-6). The high temperature plasma $(6000 \mathrm{~K}-8000 \mathrm{~K})$ source minimizes matrix effects and prevents the formation of polyatomic species during the excitation process. This in turn produces adequate sensitivity and increases the detection limits for many elements (7). The major disadvantage of ICP-AES is that it is subject to various kinds of interferences of which the spectral interference, arising from the complex nature of the emission spectra, forms the major contribution (8-11).

The rare earth elements (REEs) present line-rich spectra and their analytical wavelengths suffer a large number of interferences when the matrix constituents are other REEs (12-14). Since rare earths are increasingly needed for technological applications, they require rapid and accurate determination (15-17). Cerium (Ce) is the most abundant of the rare earth metals, found on average at the level of 66 parts per million (ppm) in the earth's crust and finds its application in nano medicine (18-19). The unique

Corresponding author.

E-mail: arijita@barc.gov.in

\section{ABSTRACT}

Cerium is the most abundant rare earth element, consisting of about $0.0046 \%$ of the Earth's crust by weight. Thus, there is a great chance for Ce to be present in most minerals and geological samples and hence, the possibility of interfering in the determination of other analytes in the samples. In this work, the spectral interference was studied on 28 analytes (rare earths, $\mathrm{Ag}, \mathrm{B}, \mathrm{Bi}$ $\mathrm{Cd}, \mathrm{Cu}, \mathrm{Ca}, \mathrm{Li}, \mathrm{Ni}, \mathrm{Sr}, \mathrm{Gd}, \mathrm{Fe}, \mathrm{Mg}$, $\mathrm{Mn}, \mathrm{Zn}, \mathrm{Dy}, \mathrm{Na}, \mathrm{Co}, \mathrm{Cr}, \mathrm{Tl}, \mathrm{Lu}$, $\mathrm{Nd}, \mathrm{Pr}, \mathrm{La}, \mathrm{Ba}, \mathrm{Ga}, \mathrm{In}, \mathrm{Al}$, and $\mathrm{Pb}$ ) in order to optimize the interference-free spectral line selection for each analyte from a high purity Ce matrix using a highly sensitive capacitive coupled device (CCD) detector-based ICPAES. The method describes the direct trace level determination of these analytes without chemical separation. The correction factor $(\mathrm{mg} / \mathrm{L})$ and analytical performance were evaluated, such as sensitivity (counts/mg/L), detection limit $(\mathrm{mg} / \mathrm{L})$, linear dynamic range, precision, and tolerance level in the presence of Ce for each selected line. The results, obtained using synthetic samples prepared from a commercially available standard reference material of the individual analytes, were found in good agreement with the method proposed.

redox properties of cerium and cerium oxide nanoparticles have led to their use in a wide variety of industrial and commercial uses such as oxygen sensors, fertilizers, as catalyst to remove toxic gases in automobile exhaust, and in nanotechnology fields (20-23). However, rare earths are not easily determined by a standard method owing to their chemical and physical similarity, their typically low concentrations, and their complex emission and absorption spectra. The ICP-AES technique for rare earth determination has superseded the use of earlier techniques, such as neutron activation analysis (2425 ) and isotope dilution mass spectrometry (26), with respect to high specificity, high sensitivity, excellent detection capability, high precision and accuracy, and complete element cover.

In this study, ICP-AES with a capacitive coupled device (CCD) detector-based system was used to determine some common analytes and the rare earths Gd, Dy, Pr, Nd, $\mathrm{La}$, and $\mathrm{Lu}$ in the presence of a Ce matrix. Several workers reported on their attempts to understand the spectral interference of REEs on other rare earths by ICP-AES with a photomultiplier tube-based detection system (27-31). However, it can be seen that the method proposed using the CCD-based detector is much more precise. Other advantages include the ability to choose alternative analytical lines of the elements. This is of great significance in a situation when the best analytically performed line of an analyte is significantly interfered by the emission-rich matrix element. The results obtained with the proposed method were validated by using synthetic samples. 


\section{EXPERIMENTAL}

\section{Instrumental and Operating Conditions}

The analysis was carried out using a model Arcos FHS12 inductively coupled plasma atomic emission spectrometer (ICP-AES) which provided a high temperature argon plasma as the source of excitation and a capacitive coupled device (CCD) as the detector system (Spectro Arcos, Germany). The operating conditions and the instrumental specifications are listed in Table I. The detector system, consisting of linear arrays of the CCD detectors (3648 pixels/array), thermally stabilized together with an optical system, provides the ability to choose alternate analytical lines (Figure 1).

\section{Standard Solutions and Reagents}

Standard solutions for all of the elements were prepared from CertiPUR ${ }^{\circledR}$ ICP standard reference material solutions of the individual elements (E-Merck, Darmstadt, Germany) by proper dilution. Suprapur ${ }^{\circledR} \mathrm{HNO}_{3}$ (E-Merck, Darmstadt, Germany) and quartz double distilled Milli-Q ${ }^{\circledR}$ water were used throughout this study. Even though ICP-AES exhibits a high degree of linear dynamic range, in order to obtain more precise calibration curves, multi-point standardization was carried out using $0.5 \mathrm{M} \mathrm{HNO}_{3}$ as a lower standard and 0.05-1000 $\mathrm{mg} / \mathrm{L}$ of the corresponding elemental standard as the higher standard for each line after proper peak search, auto-attenuation, etc. For the analysis of each sample, 10 replicate measurements were carried out, while for the determination of the detection limits and sensitivity, 25 replicate measurements were taken into account.

\section{Methods}

The method chosen for studying the spectral interference and select-
TABLE I

Specifications and Operating Conditions of ICP-AES

\begin{tabular}{ll}
\hline \multicolumn{2}{l}{ Instrumental Specifications } \\
\hline Model & Arcos FHS12 ICP-AES (Spectro Arcos) \\
Optical design & Paschen-Runge mounting, Circular design \\
Focal length & $750 \mathrm{~mm}$ \\
Grating & Holographic \\
Groove density & 1800 grooves/mm (1), 3600 grooves/mm (2) \\
Wavelength range & $130-800 \mathrm{~nm}$ \\
Entrance slit width & 15 microns \\
Resolution (FWHM) & $0.01 \mathrm{~nm}$ from $130-450 \mathrm{~nm}$ \\
& $0.02 \mathrm{~nm}$ from $450-800 \mathrm{~nm}$ \\
Thermal regulation & Controlled to $30 \pm 1^{\circ} \mathrm{C}$ \\
Frequency & $27.12 \mathrm{MHz}$ \\
Pump & Dual channel peristaltic pump \\
Detector & Linear arrays of CCD (3648 pixels/array) \\
Nebulizer & Concentric nebulizer with cyclonic spray chamber \\
ICP torch & Demountable, radial viewing \\
\hline Operating Conditions & \\
\hline Coolant flow & $16 \mathrm{~L} / \mathrm{min}$ \\
Auxiliary flow & $0.6 \mathrm{~L} / \mathrm{min}$ \\
Total time of & \\
measurement & $28 \mathrm{~s}$ \\
Pump speed & $30 \mathrm{rpm}$ \\
RF power out put & $1.2 \mathrm{~kW}$ \\
Input power & $230 \mathrm{~V}$ AC \\
\hline
\end{tabular}

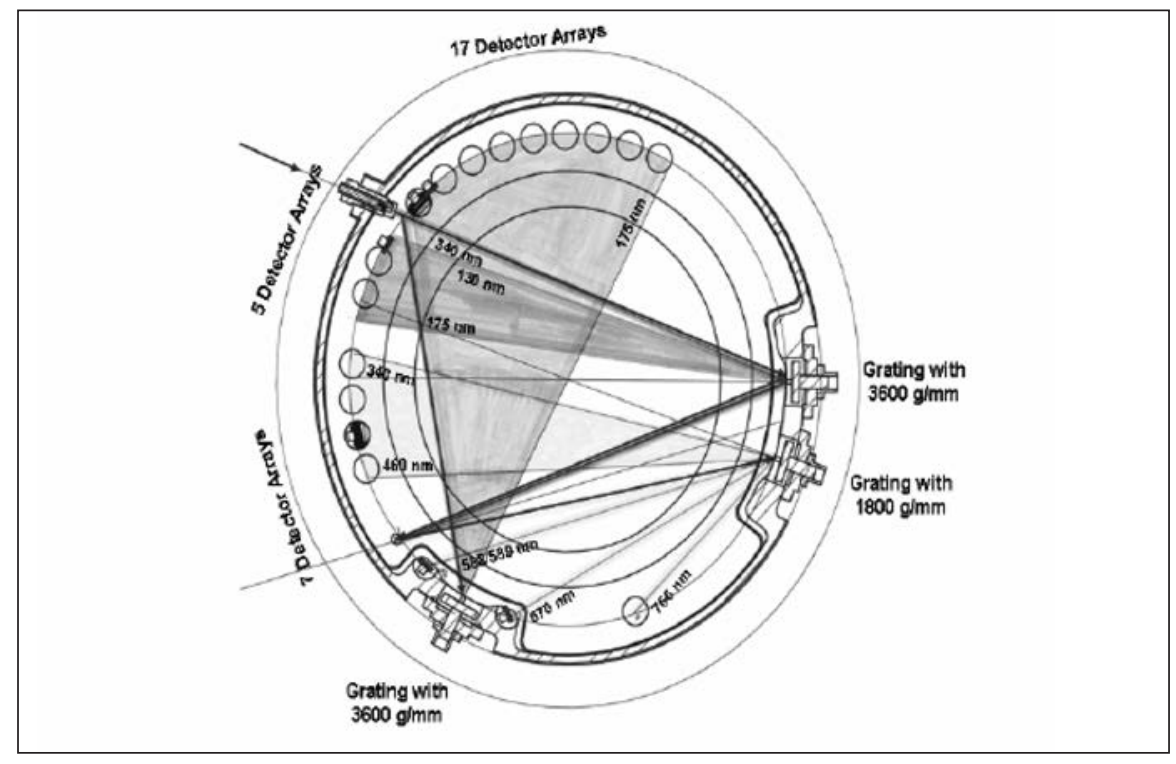

Fig. 1. Cross-sectional view of array of CCD detector. 
ing the best line(s) in the presence of Ce for each analyte was performed by preparing a series of $\mathrm{Ce}$ solutions (commercially available standard reference material elemental solutions from E-Merck, Darmstadt, Germany) of varying concentrations from $0.05 \mathrm{mg} / \mathrm{L}$ to 1000 $\mathrm{mg} / \mathrm{L}$. The contribution due to $\mathrm{Ce}$ in each different channel of each analyte was observed and the correction factor, tolerance level, along with the analytical performance (detection limit, sensitivity, linear dynamic range, and precision for each analyte) were evaluated. Using the idea of the dependence of the correction factor on the concentration of the interfering element, Ce, it becomes easy to directly determine the interferent in the presence of other analytes by ICP-AES. The analytical performance for each identified line of Ce was evaluated.

The results of the developed method for the direct trace level determination of 28 analytes in a Ce matrix were also compared with other techniques and using synthetic samples without chemical separation. Ag was determined by flame atomic absorption spectrometry (FAAS) analysis. For REE determination, ion chromatography was used, while other analytes were determined by D.C. arc carrier distillation technique.

\section{RESULTS AND DISCUSSION}

\section{Simultaneous Determination of $\mathrm{Ce}$ and the Different Analytes by ICP-AES}

Since the contribution of Ce on the different analytes is dependent on the concentration of Ce, its correct amount needs to be estimated in the sample. Also, for defining spectral interference quantitatively, the correction factor of each identified line must be known. Even though Ce is a multi-electronic atom, not all of its lines can be used for the analysis and, based on ana- lytical performance, only five lines were chosen to continue the study. The emission profiles for these five lines of Ce $(393.373 \mathrm{~nm}, 413.380$ $\mathrm{nm}, 413.765 \mathrm{~nm}, 418.660 \mathrm{~nm}$, and $448.691 \mathrm{~nm}$ ) are depicted in Figure 2 . The calibration curves for these lines were established as shown in Figure 3. The detection limit of $\mathrm{Ce}$ using these lines followed the trend: $413.380 \mathrm{~nm}<413.765 \mathrm{~nm}$ $<418.660 \mathrm{~nm}<393.373 \mathrm{~nm}<$ $448.691 \mathrm{~nm}$, while that of sensitivity followed the trend: $413.380 \mathrm{~nm}$ $\sim 413.765 \mathrm{~nm}>393.373 \mathrm{~nm}$ $>418.660 \mathrm{~nm}>448.691 \mathrm{~nm}$. The

\section{Atomic Apectroscopy \\ 1 Vol. 36(5), Sept./Oct. 2015}

slope of the calibration curves was considered as the sensitivity of the analytical lines, whereas the detection limits were calculated as the concentration equivalent to the intensity of the blank $(\langle x\rangle)+5$ times the relative standard deviation values of the blank $(5 \sigma)$. Synthetic samples containing $\mathrm{Ce}$ in the concentration range of $0.05 \mathrm{mg} / \mathrm{L}$ $1000 \mathrm{mg} / \mathrm{L}$ were analyzed using these analytical lines. The results listed in Table II show that the $393.373 \mathrm{~nm}, 413.380 \mathrm{~nm}, 413.765$ $\mathrm{nm}$, and $418.660 \mathrm{~nm}$ lines can be suitably used for the determination

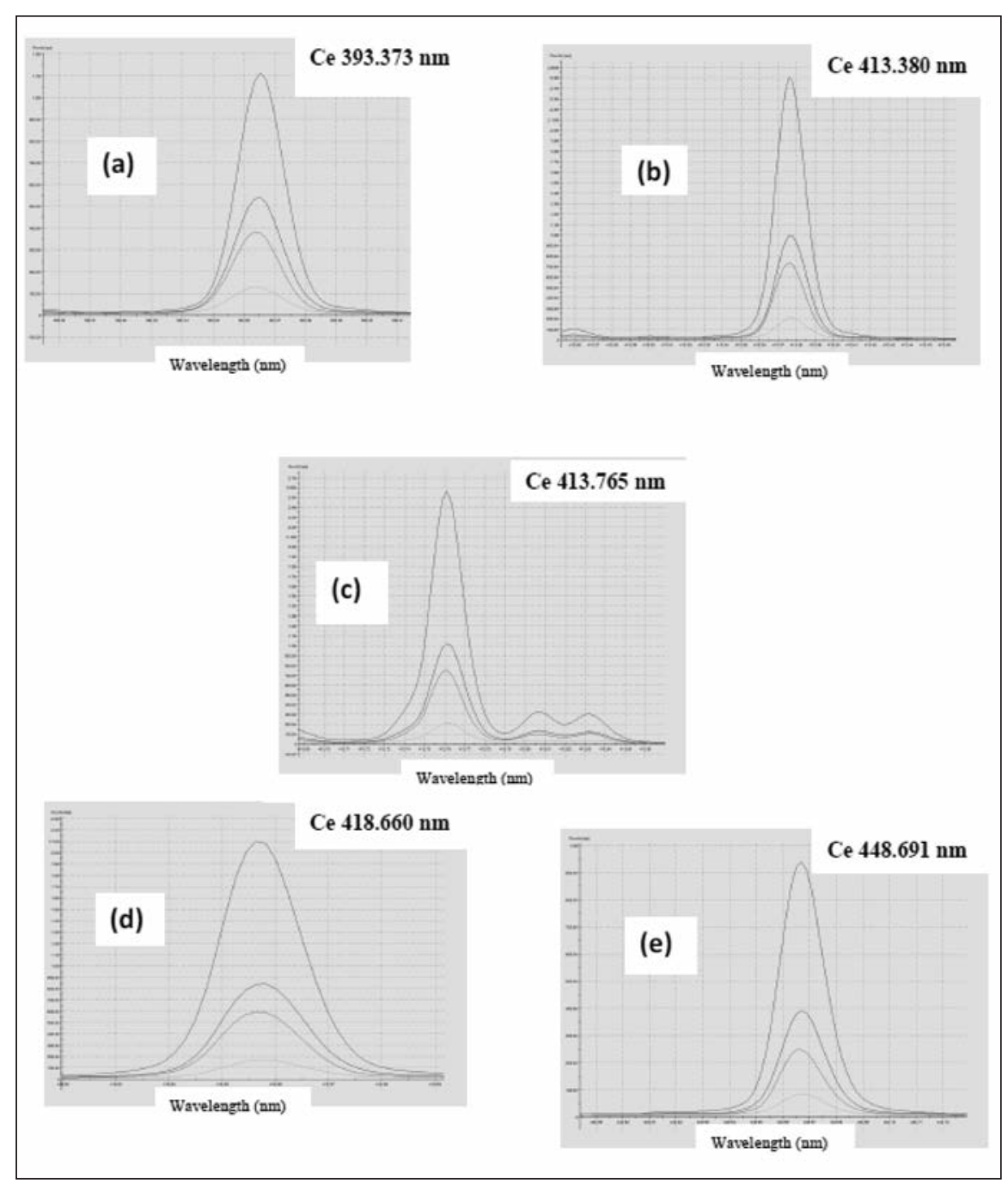

Fig. 2. Emission profiles of different analytical lines of Ce (a) $393.373 \mathrm{~nm}$, (b) $413.380 \mathrm{~nm}$, (c) $413.765 \mathrm{~nm}$, (d) $418.660 \mathrm{~nm}$, and (e) $448.691 \mathrm{~nm}$. 
of Ce up to $1000 \mathrm{mg} / \mathrm{L}$. Beyond $1000 \mathrm{mg} / \mathrm{L}$, the experiment was not carried out because of the choking problem of the nebulizer system. The study also revealed that the Ce $448.691 \mathrm{~nm}$ line was not suitable for its determination due to poor sensitivity and detection limits.

\section{Spectral Interference of Ce on Other Analytes}

Cerium, being the second member after lanthanum of the lanthanide series of 15 elements, has $[\mathrm{Xn}] 4 \mathrm{f}^{2}, 5 \mathrm{~d}^{0}, 6 \mathrm{~s}^{2}$ ground state electronic configuration and ${ }^{1} \mathrm{G}_{4}$ ground state term. The spectral study of Ce revealed various transition lines in the spectrum due to its multi-electronic nature and therefore it interfered in the determination of other analytes shown in Tables III to VIII. The best lines for each analyte were chosen based on spectral interference and analytical performance (detection limit, sensitivity, linear dynamic range, and precision).

Effect on Ag, B, Bi, Cd, Cu, Ca, Li, Ni, Sr, Gd, Fe, Mg, Mn, Zn, and Dy

The results of spectral interference for $\mathrm{Ag}, \mathrm{B}, \mathrm{Bi}, \mathrm{Cd}, \mathrm{Cu}, \mathrm{Ca}, \mathrm{Li}$, $\mathrm{Ni}, \mathrm{Sr}, \mathrm{Gd}, \mathrm{Fe}, \mathrm{Mg}, \mathrm{Mn}, \mathrm{Zn}$, and Dy are listed in Table III, while the analytical performance is listed in Table IV.

\section{Ag Lines}

Of the four lines of $\mathrm{Ag}$ (224.641 $\mathrm{nm}, 243.779 \mathrm{~nm}, 328.068 \mathrm{~nm}$, $338.289 \mathrm{~nm}$ ), only the latter two showed no interference from Ce up to $1000 \mathrm{mg} / \mathrm{L}$. The analytical performance of these two lines was similar and better, and thus $328.068 \mathrm{~nm}$ and $338.289 \mathrm{~nm}$ were chosen as the best lines for the determination of $\mathrm{Ag}$ in a Ce matrix.

\section{B Lines}

The analytical performance of the four lines of B $(249.773 \mathrm{~nm}$,

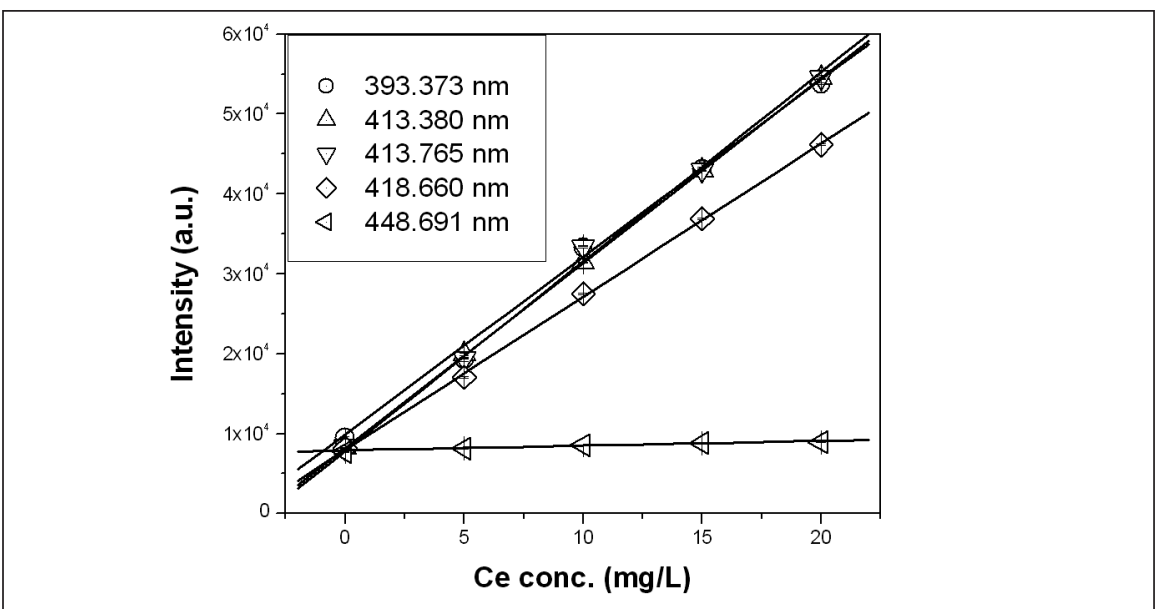

Fig. 3. Calibration curves for different analytical lines of Ce.

TABLE II

Determination of Ce by ICP-AES

\begin{tabular}{lccccc}
\hline $\begin{array}{l}\mathrm{Ce} \\
(\mathrm{mg} / \mathrm{L})\end{array}$ & $393.373 \mathrm{~nm}$ & $413.38 \mathrm{~nm}$ & $413.765 \mathrm{~nm}$ & $418.66 \mathrm{~nm}$ & $448.691 \mathrm{~nm}$ \\
\hline 1 & $0.94 \pm 0.02$ & $1.05 \pm 0.04$ & $0.98 \pm 0.04$ & $0.95 \pm 0.07$ & $0.65 \pm 0.08$ \\
5 & $5.1 \pm 0.4$ & $4.7 \pm 0.4$ & $5.2 \pm 0.3$ & $4.9 \pm 0.3$ & $7.8 \pm 0.4$ \\
10 & $10.5 \pm 0.7$ & $9.5 \pm 0.5$ & $9.7 \pm 0.6$ & $10.3 \pm 0.5$ & $8.1 \pm 0.7$ \\
20 & $18.9 \pm 0.9$ & $19.8 \pm 0.7$ & $20.5 \pm 0.6$ & $21.0 \pm 0.9$ & $24.1 \pm 0.7$ \\
50 & $48 \pm 3$ & $50 \pm 3$ & $51 \pm 2$ & $48 \pm 2$ & $44 \pm 3$ \\
100 & $97 \pm 5$ & $103 \pm 6$ & $98 \pm 4$ & $101 \pm 3$ & $113 \pm 5$ \\
500 & $492 \pm 11$ & $508 \pm 9$ & $496 \pm 11$ & $498 \pm 9$ & $508 \pm 8$ \\
1000 & $991 \pm 12$ & $1008 \pm 10$ & $997 \pm 11$ & $995 \pm 10$ & $1014 \pm 8$ \\
\hline $\begin{array}{l}\text { D.L. } \\
(\mathrm{mg} / \mathrm{L})\end{array}$ & 0.21 & 0.055 & 0.083 & 0.094 & $-^{\mathrm{a}}$ \\
$\begin{array}{l}\text { Sensitivity } \\
(\mathrm{counts} / \mathrm{mg} / \mathrm{L})\end{array}$ & 2216 & 2314 & 2312 & 1899 & $-^{\mathrm{a}}$ \\
$\begin{array}{l}\text { Linear Dynamic Range } \\
(\mathrm{mg} / \mathrm{L})\end{array}$ & $0.21-1000$ & $0.055-1000$ & $0.083-1000$ & $0.094-1000$ & $-^{\mathrm{a}}$ \\
\hline
\end{tabular}

a The Ce 448.691-nm line is not suitable for its determination.

$249.677 \mathrm{~nm}, 182.641 \mathrm{~nm}, 208.959$ $\mathrm{nm})$ were close to each other but only $208.959 \mathrm{~nm}$ showed no interference in a Ce matrix up to 1000 $\mathrm{mg} / \mathrm{L}$ and was chosen for further studies.

\section{Bi Lines}

Of the five lines of $\mathrm{Bi}$, only the $306.772 \mathrm{~nm}$ line showed no inter- ference from Ce up to $1000 \mathrm{mg} / \mathrm{L}$. The sensitivity followed the trend: $306.772 \mathrm{~nm}>223.061 \mathrm{~nm}>$ $206.170 \mathrm{~nm}>222.825 \mathrm{~nm}>$ $190.241 \mathrm{~nm}$. Thus, the $306.772 \mathrm{~nm}$ line was chosen for the determination of $\mathrm{Bi}$ in the presence of $\mathrm{Ce}$. 


\section{Atomic Apectroscopy \\ Vol. 36(5), Sept./Oct. 2015}

TABLE III

Spectral Interference of Ce on Ag, B, Bi, Cd, Cu, Ca, Li, Dy, Sr, Gd, Fe, Mg, Mn, Ni, and Zn

\begin{tabular}{|c|c|c|c|c|c|c|c|c|c|}
\hline Elements & $\begin{array}{c}\text { Analytical } \\
\text { Lines } \\
(\mathrm{nm})\end{array}$ & $\begin{array}{l}\text { Contribution } \\
\text { from } 1000 \\
\mathrm{mg} / \mathrm{L} \mathrm{of} \mathrm{Ce}\end{array}$ & $\begin{array}{l}\text { Correction } \\
\text { Interference }\end{array}$ & $\begin{array}{c}\text { Tolerance } \\
\text { Level } \\
(\mathrm{mg} / \mathrm{L})\end{array}$ & Elements & $\begin{array}{l}\text { Analytica } \\
\text { Lines } \\
(\mathrm{nm})\end{array}$ & $\begin{array}{l}\text { Contribution } \\
\text { from } 1000 \\
\mathrm{mg} / \mathrm{L} \text { of } \mathrm{Ce}\end{array}$ & $\begin{array}{l}\text { Correction } \\
\text { Interference }\end{array}$ & $\begin{array}{c}\text { Tolerance } \\
\text { Level } \\
(\mathrm{mg} / \mathrm{L})\end{array}$ \\
\hline \multirow[t]{4}{*}{ Ag } & 338.289 & $--^{a}$ & - & 1000 & \multirow[t]{3}{*}{$\mathrm{Sr}$} & 407.771 & $-{ }^{a}$ & - & 1000 \\
\hline & 328.068 & $-^{a}$ & - & 1000 & & 421.552 & $--^{a}$ & - & 1000 \\
\hline & 224.641 & 8.6 & $8.6 \times 10^{-3}$ & 100 & & 460.733 & 0.29 & $2.9 \times 10^{-4}$ & 500 \\
\hline & 243.779 & 1.2 & $1.2 \times 10^{-3}$ & 200 & \multirow[t]{4}{*}{ Gd } & 342.247 & 5.7 & $5.7 \times 10^{-3}$ & 10 \\
\hline \multirow[t]{4}{*}{ B } & 249.773 & 0.14 & $1.4 \times 10^{-4}$ & 500 & & 335.047 & 0.1 & $1.0 \times 10^{-4}$ & 500 \\
\hline & 249.677 & 0.16 & $1.6 \times 10^{-4}$ & 200 & & 336.223 & $-^{a}$ & - & 1000 \\
\hline & 182.641 & 0.29 & $2.9 \times 10^{-4}$ & 200 & & 335.862 & 0.24 & $2.4 \times 10^{-4}$ & 200 \\
\hline & 208.959 & $--^{a}$ & - & 1000 & \multirow[t]{10}{*}{$\mathrm{Fe}$} & 259.941 & 0.14 & $1.4 \times 10^{-4}$ & 500 \\
\hline \multirow[t]{5}{*}{$\mathrm{Bi}$} & 223.061 & 1.0 & $1.0 \times 10^{-3}$ & 200 & & 238.204 & 0.73 & $7.3 \times 10^{-4}$ & 100 \\
\hline & 190.241 & 19.0 & $1.9 \times 10^{-2}$ & 50 & & 239.562 & 0.17 & $1.7 \times 10^{-4}$ & 500 \\
\hline & 306.772 & $--^{a}$ & - & 1000 & & 244.451 & 2.9 & $2.9 \times 10^{-3}$ & 100 \\
\hline & 222.825 & 5.5 & $5.5 \times 10^{-3}$ & 200 & & 261.187 & 0.22 & $2.2 \times 10^{-4}$ & 200 \\
\hline & 206.170 & 2.6 & $2.6 \times 10^{-3}$ & 100 & & 262.567 & 4.6 & $4.6 \times 10^{-3}$ & 100 \\
\hline \multirow[t]{4}{*}{ Cd } & 214.438 & 0.072 & $7.2 \times 10^{5}$ & 500 & & 262.829 & 1.0 & $1.0 \times 10^{-3}$ & 200 \\
\hline & 226.502 & $--^{a}$ & - & 1000 & & 275.573 & 0.43 & $4.3 \times 10^{-4}$ & 500 \\
\hline & 228.802 & 0.37 & $3.7 \times 10^{-4}$ & 100 & & 241.331 & 1.9 & $1.9 \times 10^{-6}$ & 100 \\
\hline & 361.051 & 5.2 & $5.2 \times 10^{-3}$ & 50 & & 373.486 & $--^{a}$ & - & 1000 \\
\hline \multirow[t]{5}{*}{$\mathrm{Cu}$} & 324.754 & $-^{a}$ & - & 1000 & \multirow[t]{5}{*}{$\mathrm{Mg}$} & 279.553 & $--^{a}$ & - & $1000-$ \\
\hline & 327.396 & $--^{a}$ & - & 1000 & & 280.270 & $--^{a}$ & - & 1000 \\
\hline & 224.700 & 0.213 & $2.1 \times 10^{-4}$ & 200 & & 285.213 & 0.084 & $8.4 \times 10^{-5}$ & 500 \\
\hline & 219.226 & 0.68 & $6.8 \times 10^{-4}$ & 200 & & 279.079 & 0.41 & $4.1 \times 10^{-4}$ & 500 \\
\hline & 219.958 & 0.629 & $6.3 \times 10^{-4}$ & 50 & & 202.647 & 0.52 & $5.2 \times 10^{-4}$ & 50 \\
\hline \multirow[t]{6}{*}{$\mathrm{Ca}$} & 396.847 & 0.10 & $1.0 \times 10^{-3}$ & 100 & \multirow[t]{5}{*}{ Mn } & 257.611 & $-a$ & - & 1000 \\
\hline & 393.366 & 2.1 & $2.1 \times 10^{-3}$ & 5 & & 259.373 & 0.16 & $1.6 \times 10^{-4}$ & 200 \\
\hline & 317.933 & $--^{a}$ & - & 1000 & & 260.569 & $-^{\mathrm{a}}$ & - & 1000 \\
\hline & 315.887 & $--^{a}$ & - & 1000 & & 294.921 & 0.16 & $1.6 \times 10^{-4}$ & 500 \\
\hline & 183.801 & 5.8 & $5.8 \times 10^{-3}$ & 100 & & 403.076 & 0.50 & $5.0 \times 10^{-4}$ & 200 \\
\hline & 422.673 & 0.14 & $1.4 \times 10^{-4}$ & 200 & \multirow[t]{5}{*}{$\mathrm{Ni}$} & 231.604 & 0.67 & $6.7 \times 10^{-4}$ & $100-$ \\
\hline \multirow[t]{4}{*}{$\mathrm{Li}$} & 670.780 & $-^{a}$ & - & 1000 & & 221.648 & 0.37 & $3.7 \times 10^{-4}$ & 200 \\
\hline & 460.289 & $-^{a}$ & - & 1000 & & 232.003 & 0.39 & $3.9 \times 10^{-4}$ & 100 \\
\hline & 323.261 & 11.7 & $1.2 \times 10^{-2}$ & 10 & & 227.021 & 0.51 & $5.1 \times 10^{-4}$ & 100 \\
\hline & 274.118 & 4.5 & $4.5 \times 10^{-3}$ & 200 & & 300.249 & 0.65 & $6.5 \times 10^{-4}$ & 500 \\
\hline \multirow[t]{5}{*}{ Dy } & 353.170 & $--^{a}$ & - & 1000 & \multirow{5}{*}{$\mathrm{Zn}$} & 341.476 & $--^{a}$ & - & 1000 \\
\hline & 394.468 & 4.8 & $4.8 \times 10^{-3}$ & 10 & & 213.856 & $-^{\mathrm{a}}$ & - & 1000 \\
\hline & 340.780 & $--^{a}$ & - & 1000 & & 206.200 & 3.7 & $3.7 \times 10^{-3}$ & 50 \\
\hline & 353.602 & $--^{a}$ & - & 1000 & & 202.613 & 0.25 & $2.5 \times 10^{-4}$ & 200 \\
\hline & 364.540 & 9.1 & $9.1 \times 10^{-3}$ & 10 & & 334.502 & 4.0 & $4.0 \times 10^{-3}$ & 50 \\
\hline
\end{tabular}

Note: ${ }^{a}=$ No interference. 
TABLE IV

Analytical Performance of Ag, B, Bi, Cd, Cu, Ca, Li, Dy, Sr, Gd, Fe, Mg, Mn, Ni, and Zn ,in Presence of Ce

\begin{tabular}{|c|c|c|c|c|c|c|c|c|c|c|c|}
\hline $\begin{array}{c}\text { Ele- } \\
\text { ments }\end{array}$ & $\begin{array}{l}\text { Analytical } \\
\text { Lines } \\
(\mathrm{nm})\end{array}$ & $\begin{array}{c}\text { D.L. } \\
(\mathrm{mg} / \mathrm{L})\end{array}$ & $\begin{array}{c}\text { Sensitivity } \\
\text { (counts/ } \\
\mathrm{mg} / \mathrm{L} \text { ) }\end{array}$ & $\begin{array}{c}\text { Linear } \\
\text { Dynamic } \\
\text { Range } \\
(\mathrm{mg} / \mathrm{L})\end{array}$ & $\begin{array}{l}\%) \\
\text { RSD }\end{array}$ & $\begin{array}{l}\text { Ele- } \\
\text { ments }\end{array}$ & $\begin{array}{l}\text { Analytical } \\
\text { Lines } \\
(\mathrm{nm})\end{array}$ & $\begin{array}{c}\text { D.L. } \\
(\mathrm{mg} / \mathrm{L})\end{array}$ & $\begin{array}{c}\text { Sensitivity } \\
\text { (counts/ } \\
\text { mg/L) }\end{array}$ & $\begin{array}{l}\text { Linear } \\
\text { Dynamic } \\
\text { Range } \\
(\mathrm{mg} / \mathrm{L})\end{array}$ & $\begin{array}{r}(\%) \\
\text { RSD }\end{array}$ \\
\hline \multirow[t]{4}{*}{$\mathrm{Ag}$} & 224.641 & 1.5 & 39 & $1.5-600$ & 4.2 & Sr & 407.771 & 0.0002 & 346709 & $0.0002-1000$ & 0.88 \\
\hline & 243.779 & 0.22 & 346 & $0.22-700$ & 4.1 & & 421.552 & 0.0005 & 262155 & $0.0005-1000$ & 0.96 \\
\hline & 328.068 & 0.011 & 13737 & $0.011-1000$ & 1.2 & & 460.733 & 0.032 & 2307 & $0.032-950$ & 1.5 \\
\hline & 338.289 & 0.018 & 7156 & $0.018-1000$ & 1.1 & Gd & 335.047 & 0.007 & 6474 & $0.007-1000$ & 1.5 \\
\hline \multirow[t]{4}{*}{ B } & 182.641 & 0.024 & 757 & $0.024-800$ & 2.2 & & 335.862 & 0.015 & 3729 & $0.015-990$ & 1.9 \\
\hline & 208.959 & 0.014 & 4309 & $0.014-1000$ & 1.1 & & 336.223 & 0.026 & 4423 & $0.026-1000$ & 1.5 \\
\hline & 249.677 & 0.025 & 1013 & $0.025-1000$ & 0.95 & & 342.247 & 0.013 & 5073 & $0.013-1000$ & 2.2 \\
\hline & 249.773 & 0.013 & 1587 & $0.013-1000$ & 1.1 & $\mathrm{Fe}$ & 238.204 & 0.093 & 800 & $0.093-750$ & 3.5 \\
\hline \multirow[t]{5}{*}{$\mathrm{Bi}$} & 190.241 & 1.29 & 39 & $1.29-500$ & 3.9 & & 239.562 & 0.031 & 2063 & $0.031-1000$ & 1.0 \\
\hline & 206.170 & 0.44 & 76 & $44-600$ & 2.8 & & 241.331 & 0.26 & 229 & $0.26-650$ & 4.1 \\
\hline & 222.825 & 1.45 & 48 & $1.45-650$ & 1.8 & & 244.451 & 0.53 & 157 & $0.55-500$ & 4.8 \\
\hline & 223.061 & 0.30 & 346 & $0.30-950$ & 1.2 & & 259.941 & 0.017 & 1689 & $0.017-1000$ & 1.5 \\
\hline & 306.772 & 0.34 & 1521 & $0.34-1000$ & 0.87 & & 261.187 & 0.025 & 943 & $0.025-950$ & 2.6 \\
\hline \multirow[t]{4}{*}{$\mathrm{Cd}$} & 214.438 & 0.006 & 5244 & $0.006-1000$ & 0.66 & & 262.567 & 0.29 & 136 & $0.29-850$ & 4.1 \\
\hline & 226.502 & 0.005 & 11493 & $0.005-1000$ & 0.88 & & 262.829 & 0.37 & 194 & $0.37-800$ & 4.2 \\
\hline & 228.802 & 0.025 & 1884 & $0.025-980$ & 1.1 & & 275.573 & 0.13 & 293 & $0.13-900$ & 4.1 \\
\hline & 361.051 & 0.17 & 318 & $0.17-860$ & 2.3 & & 373.486 & 0.051 & 2173 & $0.051-1000$ & 2.2 \\
\hline \multirow[t]{5}{*}{$\mathrm{Cu}$} & 219.226 & 0.12 & 377 & $0.12-700$ & 4.3 & $\mathrm{Mg}$ & 202.647 & 0.026 & 496 & $0.026-800$ & 3.9 \\
\hline & 219.958 & 0.039 & 762 & $0.039-850$ & 2.7 & & 279.079 & 0.23 & 390 & $0.23-750$ & 4.2 \\
\hline & 224.700 & 0.037 & 1859 & $0.037-1000$ & 1.3 & & 279.553 & 0.0005 & 65352 & $0.0005-1000$ & 1.0 \\
\hline & 324.754 & 0.002 & 52029 & $0.002-1000$ & 0.64 & & 280.270 & 0.0009 & 48536 & $0.0009-1000$ & 1.1 \\
\hline & 327.396 & 0.003 & 34031 & $0.003-1000$ & 0.78 & & 285.213 & 0.0046 & 15455 & $0.0046-990$ & 1.6 \\
\hline \multirow[t]{6}{*}{$\mathrm{Ca}$} & 183.801 & 0.53 & 30 & $0.53-600$ & 4.5 & Mn & 257.611 & 0.0016 & 12854 & $0.0016-1000$ & 1.9 \\
\hline & 315.887 & 0.10 & 1114 & $0.10-750$ & 3.5 & & 259.373 & 0.0036 & 10246 & $0.0036-1000$ & 1.5 \\
\hline & 317.933 & 0.038 & 3613 & $0.038-900$ & 3.2 & & 260.569 & 0.010 & 5858 & $0.010-1000$ & 2.5 \\
\hline & 393.366 & 0.001 & 521209 & $0.001-1000$ & 1.3 & & 294.921 & 0.041 & 1832 & $0.041-800$ & 2.3 \\
\hline & 396.847 & 0.001 & 400267 & $0.001-1000$ & 1.1 & & 403.076 & 0.0025 & 9246 & $0.0025-1000$ & 1.9 \\
\hline & 422.673 & 0.004 & 25333 & $0.004-1000$ & 1.5 & $\mathrm{Ni}$ & 221.648 & 0.12 & 848 & $0.12-700$ & 2.9 \\
\hline \multirow[t]{4}{*}{$\mathrm{Li}$} & 274.118 & 0.80 & 41 & $0.81-600$ & 3.8 & & 227.021 & 0.046 & 154 & $0.046-800$ & 3.2 \\
\hline & 323.261 & 0.047 & 199 & $0.047-850$ & 2.5 & & 231.604 & 0.014 & 853 & $0.014-850$ & 3.9 \\
\hline & 460.289 & 0.18 & 201 & $0.18-950$ & 2.4 & & 232.003 & 0.068 & 703 & $0.068-1000$ & 4.2 \\
\hline & 670.780 & 0.0009 & 200525 & $0.0009-1000$ & 1.0 & & 300.249 & 0.11 & 642 & $0.11-750$ & 2.9 \\
\hline \multirow[t]{5}{*}{ Dy } & 340.780 & 0.02 & 4300 & $0.02-750$ & 2.9 & & 341.476 & 0.012 & 4201 & $0.012-1000$ & 2.2 \\
\hline & 353.170 & 0.020 & 14075 & $0.02-1000$ & 1.5 & $\mathrm{Zn}$ & 202.613 & 0.008 & 2058 & $0.008-1000$ & 1.3 \\
\hline & 353.602 & 0.053 & 4040 & $0.053-1000$ & 1.7 & & 206.200 & 0.21 & 157 & $0.21-500$ & 4.6 \\
\hline & 364.540 & 0.031 & 4864 & $0.031-1000$ & 1.9 & & 213.856 & 0.001 & 18061 & $0.001-1000$ & 1.1 \\
\hline & 394.468 & 0.042 & 3884 & $0.042-950$ & 2.1 & & 334.502 & 0.12 & 453 & $0.12-600$ & 4.1 \\
\hline
\end{tabular}




\section{Cd Lines}

The detection limit trend for the four lines of Cd was $226.502 \mathrm{~nm}<$ $214.438 \mathrm{~nm}<228.802 \mathrm{~nm}<$ $361.051 \mathrm{~nm}$, while the trend for sensitivity was completely reversed. Also, the $226.502 \mathrm{~nm}$ line was the only line not interfering in a Ce matrix up to $1000 \mathrm{mg} / \mathrm{L}$, and thus was chosen for further studies.

\section{Cu Lines}

Of the $324.754 \mathrm{~nm}, 327.396 \mathrm{~nm}$, $219.226 \mathrm{~nm}, 219.958 \mathrm{~nm}$ and $224.700 \mathrm{~nm}$ Cu lines, only 324.754 $\mathrm{nm}$ and $327.396 \mathrm{~nm}$ showed no interference in a Ce matrix up to $1000 \mathrm{mg} / \mathrm{L}$. The analytical performance of these lines was found to be close to each other and superior over the other lines. Thus, 324.754 $\mathrm{nm}$ and $327.396 \mathrm{~nm}$ were considered the best lines for the determination of $\mathrm{Cu}$ in $\mathrm{Ce}$ matrix.

\section{Ca Lines}

Out of the six lines of $\mathrm{Ca}$ (396.847 nm, $393.366 \mathrm{~nm}, 317.933$ $\mathrm{nm}, 315.887 \mathrm{~nm}, 183.801 \mathrm{~nm}$, $422.673 \mathrm{~nm}$ ), only two lines $(317.933 \mathrm{~nm}$ and $315.887 \mathrm{~nm})$ were found not to be interfered by Ce up to $1000 \mathrm{mg} / \mathrm{L}$. Comparing the analytical performances of these two lines revealed that the $317.933 \mathrm{~nm}$ line (detection limit: $0.03874 \mathrm{mg} / \mathrm{L}$ and sensitivity: 3613 counts/mg/L) must be chosen over 315.887 nm (detection limit: 0.103 $\mathrm{mg} / \mathrm{L}$ and sensitivity: 1114 counts/ $\mathrm{mg} / \mathrm{L}$ ) for further studies of $\mathrm{Ca}$ in a Ce matrix.

\section{Li Lines}

Among the four lines of $\mathrm{Li}$ (323.261 nm, $274.118 \mathrm{~nm}, 670.780$ $\mathrm{nm}$, and $460.289 \mathrm{~nm})$, two lines $(670.780 \mathrm{~nm}$ and $460.289 \mathrm{~nm})$ showed no interference from Ce up to $1000 \mathrm{mg} / \mathrm{L}$. However, the analytical performance of the $670.780 \mathrm{~nm}$ line was much better and thus found to be best for the determination of $\mathrm{Li}$ in a Ce matrix.

\section{Ni Lines}

Of the six lines of $\mathrm{Ni}$, only the $341.476 \mathrm{~nm}$ line was found not to be interfered by Ce. The detection limit followed the trend: 341.476 $\mathrm{nm}<231.604 \mathrm{~nm}<227.021 \mathrm{~nm}<$ $232.003 \mathrm{~nm}<300.249 \mathrm{~nm}<$ $221.648 \mathrm{~nm}$. Thus, on the basis of both spectral interference and analytical performance, the 341.476 $\mathrm{nm}$ line was chosen for the determination of $\mathrm{Ni}$ in a Ce matrix.

\section{Sr Lines}

Of the three lines of $\mathrm{Sr}(407.771$ $\mathrm{nm}, 421.552 \mathrm{~nm}$, and $460.733 \mathrm{~nm})$, the first two lines were found not to be interfered in a Ce matrix. The analytical performance of these two lines was very similar for both and better than the $460.733 \mathrm{~nm}$ line. Thus, these two lines were chosen as the best lines for the determination of $\mathrm{Sr}$ in the presence of Ce.

\section{Gd Lines}

The analytical performance of the four lines of $\mathrm{Gd}(342.247 \mathrm{~nm}$, $335.047 \mathrm{~nm}, 336.223 \mathrm{~nm}$, and $335.862 \mathrm{~nm}$ ) were found close to each other, leaving spectral interference as the criterion for the determination of Gd in a Ce matrix. The only line not to interfere in the presence of Ce was $336.223 \mathrm{~nm}$, and was thus chosen as the best line for further studies of $\mathrm{Gd}$ in a Ce matrix.

\section{Fe Lines}

Out of 10 lines of Fe, the only line not to be interfered by Ce was $373.486 \mathrm{~nm}$. The sensitivity followed the trend: $373.486 \mathrm{~nm}>$ $239.562 \mathrm{~nm}>259.941 \mathrm{~nm}>$ $261.187 \mathrm{~nm}>238.204 \mathrm{~nm}>$ $257.573 \mathrm{~nm}>241.331 \mathrm{~nm}>$ $262.829 \mathrm{~nm}>244.451 \mathrm{~nm}>$ $262.567 \mathrm{~nm}$. Thus, the $373.486 \mathrm{~nm}$ line was chosen for the determination of $\mathrm{Fe}$ in the presence of Ce.

\section{Mg Lines}

The detection limit of two (279.553 $\mathrm{nm}$ and $280.270 \mathrm{~nm}$ ) of

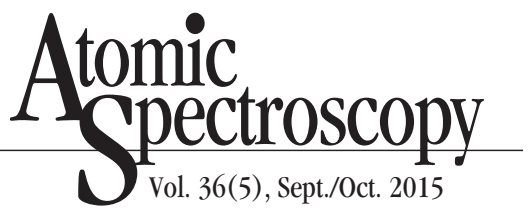

the five lines $(279.553 \mathrm{~nm}, 280.270$ $\mathrm{nm}, 285.213 \mathrm{~nm}, 279.079 \mathrm{~nm}$, $202.647 \mathrm{~nm}$ ) of $\mathrm{Mg}$ were found to be very similar and better than the other ones. In addition, these two lines of $\mathrm{Mg}$ did not show any significant interference from Ce up to $1000 \mathrm{mg} / \mathrm{L}$ and were chosen as the best lines for the determination of $\mathrm{Mg}$ in a Ce matrix.

\section{Mn Lines}

Of the five lines of $\mathrm{Mn}$ (257.611 $\mathrm{nm}, 259.373 \mathrm{~nm}, 260.569 \mathrm{~nm}$, $294.921 \mathrm{~nm}$ and $403.076 \mathrm{~nm}$ ), the two lines of $257.611 \mathrm{~nm}$ and $260.569 \mathrm{~nm}$ did not show to be interfered in a Ce matrix up to $1000 \mathrm{mg} / \mathrm{L}$. The analytical performance for all $\mathrm{Mn}$ lines ranged from 5\%-10\% RSD. So, relying on spectral interference, the $257.611 \mathrm{~nm}$ and $260.569 \mathrm{~nm}$ lines were considered best for Mn determination in a Ce matrix.

\section{Zn Lines}

The four lines of $\mathrm{Zn}$ chosen for this study were $213.856 \mathrm{~nm}$, $206.200 \mathrm{~nm}, 202.613 \mathrm{~nm}$, and $334.502 \mathrm{~nm}$. The only line which showed no interference in a Ce matrix up to $1000 \mathrm{mg} / \mathrm{L}$ was $213.856 \mathrm{~nm}$. The detection limit followed the trend: $213.856 \mathrm{~nm}<$ $202.613 \mathrm{~nm}<334.502 \mathrm{~nm}<$ 206.200 nm, while the trend for sensitivity was completely reversed. Thus, the $213.856 \mathrm{~nm}$ line of $\mathrm{Zn}$ was selected as the best line for further studies in the presence of Ce.

\section{Dy Lines}

The detection limit for the five lines of Dy $(353.170 \mathrm{~nm}, 340.78$ $\mathrm{nm}, 353.602 \mathrm{~nm}, 394.468 \mathrm{~nm}$, and $364.54 \mathrm{~nm}$ ) was found to range from 5\%-10\% RSD and therefore was acceptable. Three of the five lines $(353.170 \mathrm{~nm}, 340.780 \mathrm{~nm}$, and $353.602 \mathrm{~nm}$ ) were found not to be interfered by Ce and were chosen as the best lines for the determination of Dy in a Ce matrix. 
TABLE V

Spectral Interference of Ce on $\mathrm{Na}, \mathrm{Co}, \mathrm{Cr}, \mathrm{Tl}, \mathrm{Lu}, \mathrm{Nd}, \mathrm{Pr}$, and $\mathrm{La}$

\begin{tabular}{|c|c|c|c|c|c|c|c|c|c|}
\hline Elements & $\begin{array}{c}\text { Analytical } \\
\text { Lines } \\
(\mathrm{nm})\end{array}$ & $\begin{array}{l}\text { Contribution } \\
\text { from } 1000 \\
\text { mg/L of Ce }\end{array}$ & $\begin{array}{c}\text { Correction } \\
\text { Factor }\end{array}$ & $\begin{array}{c}\text { Tolerance } \\
\text { Level } \\
(\mathrm{mg} / \mathrm{L})\end{array}$ & Elements & $\begin{array}{l}\text { Analytical } \\
\text { Lines } \\
(\mathrm{nm})\end{array}$ & $\begin{array}{l}\text { Contribution } \\
\text { from } 1000 \\
\mathrm{mg} / \mathrm{L} \text { of } \mathrm{Ce}\end{array}$ & $\begin{array}{l}\text { Correction } \\
\text { Factor }\end{array}$ & $\begin{array}{c}\text { Tolerance } \\
\text { Level } \\
(\mathrm{mg} / \mathrm{L})\end{array}$ \\
\hline \multirow[t]{4}{*}{$\mathrm{Na}$} & 589.592 & 0.09 & $9 \times 10^{-5}$ & 500 & \multirow[t]{4}{*}{$\mathrm{Lu}$} & 261.542 & 0.10 & $1.0 \times 10^{-4}$ & 500 \\
\hline & 588.995 & 0.08 & $8 \times 10^{-5}$ & 500 & & 291.139 & 0.11 & $1.1 \times 10^{-4}$ & 500 \\
\hline & 330.237 & $-{ }^{a}$ & - & 1000 & & 307.76 & 3.7 & $3.7 \times 10^{-3}$ & 10 \\
\hline & 330.298 & 11.2 & $1.1 \times 10^{-2}$ & 500 & & 219.554 & 0.30 & $3.0 \times 10^{-4}$ & 200 \\
\hline \multirow[t]{4}{*}{ Co } & 228.616 & 0.59 & $5.9 \times 10^{-4}$ & 100 & \multirow[t]{4}{*}{$\mathrm{Nd}$} & 401.225 & $-{ }^{b}$ & Rejected & 0.05 \\
\hline & 238.892 & 0.13 & $1.3 \times 10^{-4}$ & 500 & & 430.358 & 0.24 & $2.4 \times 10^{-4}$ & 200 \\
\hline & 230.786 & 0.57 & $5.7 \times 10^{-4}$ & 200 & & 406.109 & 0.80 & $8.0 \times 10^{-4}$ & 200 \\
\hline & 237.862 & 0.24 & $2.4 \times 10^{-4}$ & 200 & & 417.731 & 0.54 & $5.4 \times 10^{-4}$ & 200 \\
\hline \multirow[t]{5}{*}{$\mathrm{Cr}$} & 267.716 & 0.36 & $3.6 \times 10^{-4}$ & 200 & \multirow[t]{4}{*}{$\operatorname{Pr}$} & 411.846 & 5.5 & $5.5 \times 10^{-3}$ & 10 \\
\hline & 205.618 & 0.12 & $1.2 \times 10^{-4}$ & 500 & & 417.939 & 4.7 & $4.7 \times 10^{-3}$ & 10 \\
\hline & 283.563 & 0.52 & $5.2 \times 10^{-4}$ & 100 & & 422.535 & 0.13 & $1.3 \times 10^{-4}$ & 500 \\
\hline & 284.325 & 0.17 & $1.7 \times 10^{-4}$ & 500 & & 414.311 & 1.8 & $1.8 \times 10^{-3}$ & 100 \\
\hline & 284.984 & 0.69 & $6.9 \times 10^{-4}$ & 50 & \multirow[t]{3}{*}{$\mathrm{La}$} & 408.672 & 3.0 & $3.0 \times 10^{-3}$ & 10 \\
\hline \multirow[t]{2}{*}{$\mathrm{Tl}$} & 190.864 & 0.32 & $3.2 \times 10^{-4}$ & 200 & & 333.749 & 0.19 & $1.9 \times 10^{-4}$ & 500 \\
\hline & 276.787 & 6.0 & $6.0 \times 10^{-3}$ & 200 & & 379.478 & 5.4 & $5.4 \times 10^{-3}$ & 5 \\
\hline
\end{tabular}

${ }^{a}=$ No Interference.

$\mathrm{b}=$ Significant Interaction,

TABLE VI

Analytical performance of $\mathrm{Na}, \mathrm{Co}, \mathrm{Cr}, \mathrm{Tl}, \mathrm{Lu}, \mathrm{Nd}, \mathrm{Pr}$ and $\mathrm{La}$ in Presence of Ce

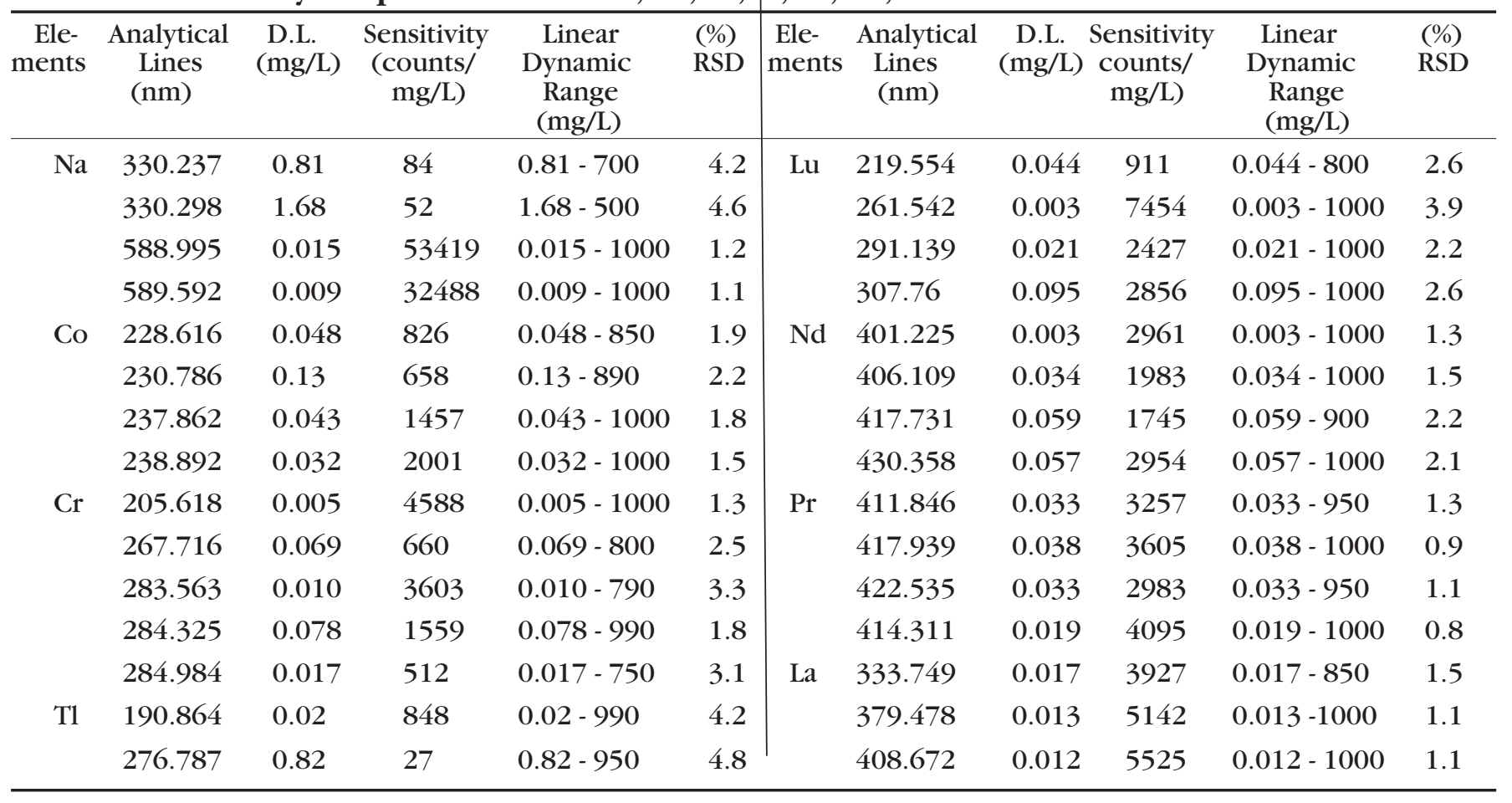


Effect of Ce on Na, Co, Cr, Tl, $\mathrm{Lu}, \mathrm{Nd}, \mathrm{P}, \mathbf{r}$ and $\mathrm{La}$

The results of spectral interference of these analytes on Ce is shown in Table V, while that of analytical performance is shown in Table VI.

\section{Co Lines}

The four lines of Co showed some interference in a Ce matrix. The least interfered line was $238.892 \mathrm{~nm}$. The detection limit followed the trend: $238.892 \mathrm{~nm}<$ $237.862 \mathrm{~nm}<228.616 \mathrm{~nm}<$ $230.786 \mathrm{~nm}$, while the trend for sensitivity was completely reverse. Therefore, the Co $238.892 \mathrm{~nm}$ line was considered best for the determination of Co in a Ce matrix.

\section{Cr Lines}

The spectral interference of Ce on the five lines of $\mathrm{Cr}$ followed the trend: $205.618 \mathrm{~nm}<284.325 \mathrm{~nm}<$ $267.716 \mathrm{~nm}<283.563 \mathrm{~nm}<$

$284.984 \mathrm{~nm}$. The analytical performance (detection limit and sensitivity) for the $205.618 \mathrm{~nm}$ line was found superior over the other lines and hence, chosen as the best line for the determination of $\mathrm{Cr}$ in a $\mathrm{Ce}$ matrix.

\section{T1 Lines}

The two lines of Tl (190.864 nm and $267.787 \mathrm{~nm}$ ) were interfered by $\mathrm{Ce}$, but least interference was at $190.864 \mathrm{~nm}$. The analytical performance of the $190.864 \mathrm{~nm}$ line of $\mathrm{Tl}$ was better than for the $267.787 \mathrm{~nm}$ line, and was chosen for further studies in the presence of Ce.

\section{Lu Lines}

The spectral interference of Ce on four lines of Lu followed the trend: $261.542 \mathrm{~nm}<291.139 \mathrm{~nm}<$ $219.554 \mathrm{~nm}<307.760 \mathrm{~nm}$. The analytical performance of the $261.542 \mathrm{~nm}$ line (detection limit $0.003318 \mathrm{mg} / \mathrm{L}$ and sensitivity 7454 counts/mg/L) was found superior over other ones and hence, this line of Lu was chosen for the determination of Lu in a Ce matrix.

\section{Nd Lines}

Out of four lines of $\mathrm{Nd}$ ( 401.225 $\mathrm{nm}, 430.358 \mathrm{~nm}, 406.109 \mathrm{~nm}$, and $417.731 \mathrm{~nm}$ ), the $401.225 \mathrm{~nm}$ line was severely interfered by $\mathrm{Ce}$, while the $430.358 \mathrm{~nm}$ line was least interfered. The analytical performance of all the lines ranged from $5 \%-10 \%$ RSD. Thus from the spectral interference criterion, the $430.358 \mathrm{~nm}$ line, with a tolerance level of $200 \mathrm{mg} / \mathrm{L}$, was chosen for the study of $\mathrm{Nd}$ in presence of Ce.

\section{Pr Lines}

The four Pr lines ( $411.846 \mathrm{~nm}$, $417.939 \mathrm{~nm}, 422.535 \mathrm{~nm}$, and $414.311 \mathrm{~nm}$ ) chosen for this study showed interference from Ce, and the $422.535 \mathrm{~nm}$ line with a tolerance level $500 \mathrm{mg} / \mathrm{L}$ was found to be least interfered. The analytical performance for all lines was close to each other and thus does not contribute much in the selection for best line. With regard to spectral interference, the $422.535 \mathrm{~nm}$ line was considered the best for the determination of Pr in a Ce matrix.

\section{La Lines}

The analytical performance for the three lines of $\mathrm{La}(408.672 \mathrm{~nm}$, $333.749 \mathrm{~nm}$, and $379.478 \mathrm{~nm}$ ) were almost similar leaving the spectral interference as the only criterion for selecting the best line. The least interfered line was $333.749 \mathrm{~nm}$ with a tolerance level of $500 \mathrm{mg} / \mathrm{L}$, and thus was chosen for La determination in the presence of Ce.

\section{Effect of $\mathrm{Ba}, \mathrm{Ga}, \mathrm{In}, \mathrm{Al}$, and $\mathrm{Pb}$}

The results of spectral interference of $\mathrm{Ba}, \mathrm{Ga}, \mathrm{In}, \mathrm{Al}$, and $\mathrm{Pb}$ in a Ce matrix are listed in Table VII, and the analytical performance is listed in Table VIII.

\section{Ba Lines}

The first two of the three lines of $\mathrm{Ba}(455.404 \mathrm{~nm}, 230.424 \mathrm{~nm}$, and $233.527 \mathrm{~nm}$ ) showed almost similar contribution (1.3 and 1.5 , respectively) and the analytical perfor-mance (detection limit: 0.028 and 0.012 , respectively) and thus both of these lines ( $455.404 \mathrm{~nm}$ and $230.424 \mathrm{~nm}$ ) were regarded best for the determination of $\mathrm{Ba}$ in a Ce matrix.

\section{Ga Lines}

Of the three lines of Ga (417.206 $\mathrm{nm}, 294.364 \mathrm{~nm}$, and $287.424 \mathrm{~nm}$ ), the least interfered is $287.424 \mathrm{~nm}$, but it showed poor analytical performance. The best analytical performance was acquired by the $417.206 \mathrm{~nm}$ line but it showed significant interference in a Ce matrix. The result for the $294.364 \mathrm{~nm}$ line was moderate and acceptable and, therefore, this line was chosen as the best line to study $\mathrm{Ga}$ in a Ce matrix.

\section{In Lines}

Of the four lines of In (230.606 $\mathrm{nm}, 325.609 \mathrm{~nm}, 451.131 \mathrm{~nm}$, and $303.936 \mathrm{~nm}$ ), the $451.131 \mathrm{~nm}$ line showed severe interference in a Ce matrix. The contribution of Ce on the $230.606 \mathrm{~nm}$ and $325.609 \mathrm{~nm}$ lines was very similar and the analytical performance deviated little, while the $303.936 \mathrm{~nm}$ line showed significant interaction. Therefore, both the $230.606 \mathrm{~nm}$ and 325.609 $\mathrm{nm}$ lines were chosen for the determination of In in the presence of Ce.

\section{Al Lines}

Of the four lines of $\mathrm{Al}$ (308.215 $\mathrm{nm}, 396.152 \mathrm{~nm}, 394.401 \mathrm{~nm}$, and $309.271 \mathrm{~nm}$ ), only the latter line was not interfered by Ce, but it has the worst analytical performance. Line $396.152 \mathrm{~nm}$ was least interfered by Ce and due to the detection limit trend: $396.152 \mathrm{~nm}$ $<394.401 \mathrm{~nm}<308.215 \mathrm{~nm}<$ $309.271 \mathrm{~nm}$ and was considered the best choice for the analysis of $\mathrm{Al}$ in the presence of Ce. 


\section{Pb Lines}

The contribution of Ce on the four lines of $\mathrm{Pb}$ followed the trend: $283.305 \mathrm{~nm}<405.778 \mathrm{~nm}<$ $220.353<261.418 \mathrm{~nm}$. The trend for the detection limit was: 283.305 $\mathrm{nm}<220.353 \mathrm{~nm} \sim 405.778 \mathrm{~nm}$ $<261.418 \mathrm{~nm}$. Thus, considering both parameters, the best line for the determination of $\mathrm{Pb}$ in the presence of Ce was $283.305 \mathrm{~nm}$.

\section{Gd, Nd, Ga, Pr, and Dy Lines}

The typical spectral interference of Ce on Gd 342.247 nm, Nd 401.22 nm, Ga 417.206 nm, Pr
$411.846 \mathrm{~nm}$, and Dy $394.468 \mathrm{~nm}$ is shown in Figure 4. It should also be mentioned that the contribution of Ce on the different analytical lines of the elements varied linearly with the Ce concentration. Figure 5 shows the variation of Ce contribution on some specified analytical

TABLE VII

Spectral Interference of $\mathrm{Ce}$ on $\mathrm{Ba}, \mathrm{Ga}, \mathrm{In}, \mathrm{Al}$, and $\mathrm{Pb}$

\begin{tabular}{|c|c|c|c|c|c|c|c|c|c|}
\hline $\begin{array}{l}\text { Ele- } \\
\text { ments }\end{array}$ & $\begin{array}{l}\text { Analytical } \\
\text { Lines } \\
(\mathrm{nm})\end{array}$ & $\begin{array}{l}\text { Contribution } \\
\text { from } 1000 \\
\mathrm{mg} / \mathrm{L} \text { of } \mathrm{Ce}\end{array}$ & $\begin{array}{c}\text { Correction } \\
\text { Factor }\end{array}$ & $\begin{array}{c}\text { Tolerance } \\
\text { Level } \\
(\mathrm{mg} / \mathrm{L})\end{array}$ & $\begin{array}{c}\text { Ele- } \\
\text { ments }\end{array}$ & $\begin{array}{l}\text { Analytical } \\
\text { Lines } \\
(\mathrm{nm})\end{array}$ & $\begin{array}{l}\text { Contribution } \\
\text { from } 1000 \\
\mathrm{mg} / \mathrm{L} \text { of } \mathrm{Ce}\end{array}$ & $\begin{array}{c}\text { Correction } \\
\text { Factor }\end{array}$ & $\begin{array}{c}\text { Tolerance } \\
\text { Level } \\
(\mathrm{mg} / \mathrm{L})\end{array}$ \\
\hline \multirow[t]{3}{*}{$\mathrm{Ba}$} & 455.404 & 1.3 & $1.3 \times 10^{-3}$ & 200 & \multirow[t]{3}{*}{$\mathrm{Al}$} & 396.152 & 1.5 & $1.5 \times 10^{-3}$ & 50 \\
\hline & 233.527 & 1.8 & $1.8 \times 10^{-3}$ & 50 & & 394.401 & a & Rejected & 0.05 \\
\hline & 230.424 & 1.5 & $1.5 \times 10^{-3}$ & 50 & & 308.215 & 3.2 & $3.2 \times 10^{-3}$ & 10 \\
\hline \multirow[t]{3}{*}{ Ga } & 417.206 & 9 & $9.0 \times 10^{-3}$ & 10 & \multirow{3}{*}{$\mathrm{Pb}$} & 309.271 & $\mathrm{ab}$ & - & 1000 \\
\hline & 294.364 & 3.8 & $3.8 \times 10^{-3}$ & 10 & & 220.353 & 1.3 & $1.3 \times 10^{-3}$ & 100 \\
\hline & 287.424 & 1.9 & $1.9 \times 10^{-3}$ & 200 & & 405.778 & 0.82 & $8.2 \times 10^{-4}$ & 500 \\
\hline \multirow[t]{4}{*}{ In } & 230.606 & 0.84 & $8.4 \times 10^{-4}$ & 100 & & 283.305 & 0.47 & $4.7 \times 10^{-4}$ & 100 \\
\hline & 325.609 & 0.69 & $6.9 \times 10^{-4}$ & 200 & & 261.418 & 4.3 & $4.3 \times 10^{-3}$ & 50 \\
\hline & 451.131 & a & Rejected & & & & & & \\
\hline & 303.936 & 4.9 & $4.9 \times 10^{-3}$ & 50 & & & & & \\
\hline
\end{tabular}

Note $:$ a $=$ Significant Interference.,

${ }^{\mathrm{ab}}=$ No Interference.

TABLE VIII

Analytical Performance of $\mathrm{Ba}, \mathrm{Ga}, \mathrm{In}, \mathrm{Al}$, and $\mathrm{Pb}$ in Presence of $\mathrm{Ce}$

\begin{tabular}{|c|c|c|c|c|c|c|c|c|c|c|c|}
\hline $\begin{array}{l}\text { Ele- } \\
\text { ments }\end{array}$ & $\begin{array}{c}\text { Analytical } \\
\text { Lines } \\
\text { (nm) }\end{array}$ & $\begin{array}{l}\text { D.L. } \\
\text { (mg/L) }\end{array}$ & $\begin{array}{c}\text { Sensitivity } \\
\text { (counts/ } \\
\mathrm{mg} / \mathrm{L} \text { ) }\end{array}$ & $\begin{array}{c}\text { Linear } \\
\text { Dynamic } \\
\text { Range } \\
(\mathrm{mg} / \mathrm{L})\end{array}$ & $\begin{array}{l}\text { (\%) } \\
\text { RSD }\end{array}$ & $\begin{array}{l}\text { Ele- } \\
\text { ments }\end{array}$ & $\begin{array}{l}\text { Analytical } \\
\text { Lines } \\
\text { (nm) }\end{array}$ & $\begin{array}{c}\text { D.L. } \\
(\mathrm{mg} / \mathrm{L})\end{array}$ & $\begin{array}{l}\text { Sensitivity } \\
\text { counts/ } \\
\mathrm{mg} / \mathrm{L})\end{array}$ & $\begin{array}{l}\text { Linear } \\
\text { Dynamic } \\
\text { Range } \\
(\mathrm{mg} / \mathrm{L})\end{array}$ & $\begin{array}{l}(\%) \\
\text { RSD }\end{array}$ \\
\hline \multirow[t]{3}{*}{$\mathrm{Ba}$} & 230.424 & 0.011 & 793 & $0.011-1000$ & 2.5 & \multirow[t]{3}{*}{$\mathrm{Al}$} & 308.215 & 0.036 & 1821 & $0.036-950$ & 2.2 \\
\hline & 233.527 & 0.091 & 388 & $0.091-800$ & 2.9 & & 309.271 & 1.88 & 3130 & $1.88-800$ & 2.9 \\
\hline & 455.404 & 0.027 & 2479 & $0.021-1000$ & 1.1 & & 394.401 & 0.016 & 3109 & $0.016-1000$ & 2.2 \\
\hline \multirow[t]{3}{*}{$\mathrm{Ga}$} & 287.424 & 0.26 & 182 & $0.26-850$ & 4.6 & \multirow{3}{*}{$\mathrm{Pb}$} & 396.152 & 0.013 & 10037 & $0.013-1000$ & 1.1 \\
\hline & 294.364 & 0.031 & 864 & $0.031-1000$ & 3.9 & & 220.353 & 0.12 & 275 & $0.12-900$ & 4.3 \\
\hline & 417.206 & 0.033 & 7693 & $0.033-1000$ & 0.9 & & 261.418 & 0.28 & 99 & $0.28-800$ & 4.1 \\
\hline \multirow[t]{4}{*}{ In } & 230.606 & 0.069 & 577 & $0.069-1000$ & 4.2 & & 283.305 & 0.068 & 719 & $0.068-950$ & 2.2 \\
\hline & 303.936 & 0.1 & 535 & $0.10-800$ & 4.8 & & 405.778 & 0.12 & 777 & $0.12-950$ & 2.9 \\
\hline & 325.609 & 0.074 & 1489 & $0.074-1000$ & 2.5 & & & & & & \\
\hline & 451.131 & 8.4 & 31 & $8.4-500$ & 4.9 & & & & & & \\
\hline
\end{tabular}




\section{Atomic Apectroscopy \\ 1 Vol. 36(5), Sept./Oct. 2015}

lines of all the elements (due to the spectral interference) as a function of Ce concentration. Though the linear relationship was found to be valid for all of the analytical lines, for the clarity of presentation, only a single analytical line of each element is represented in Figure 5.
Validation of Method for the Direct Determination of Analytes in a Ce Matrix

The method proposed and developed for the direct determination of analytes in the presence of a high purity cerium matrix and selecting the best line for each ana- lyte was validated by using six sets of synthetic samples, prepared from commercially available standard reference materials of the individual elemental solutions. The samples were then fed to the hotter argon plasma and the results obtained were analyzed without
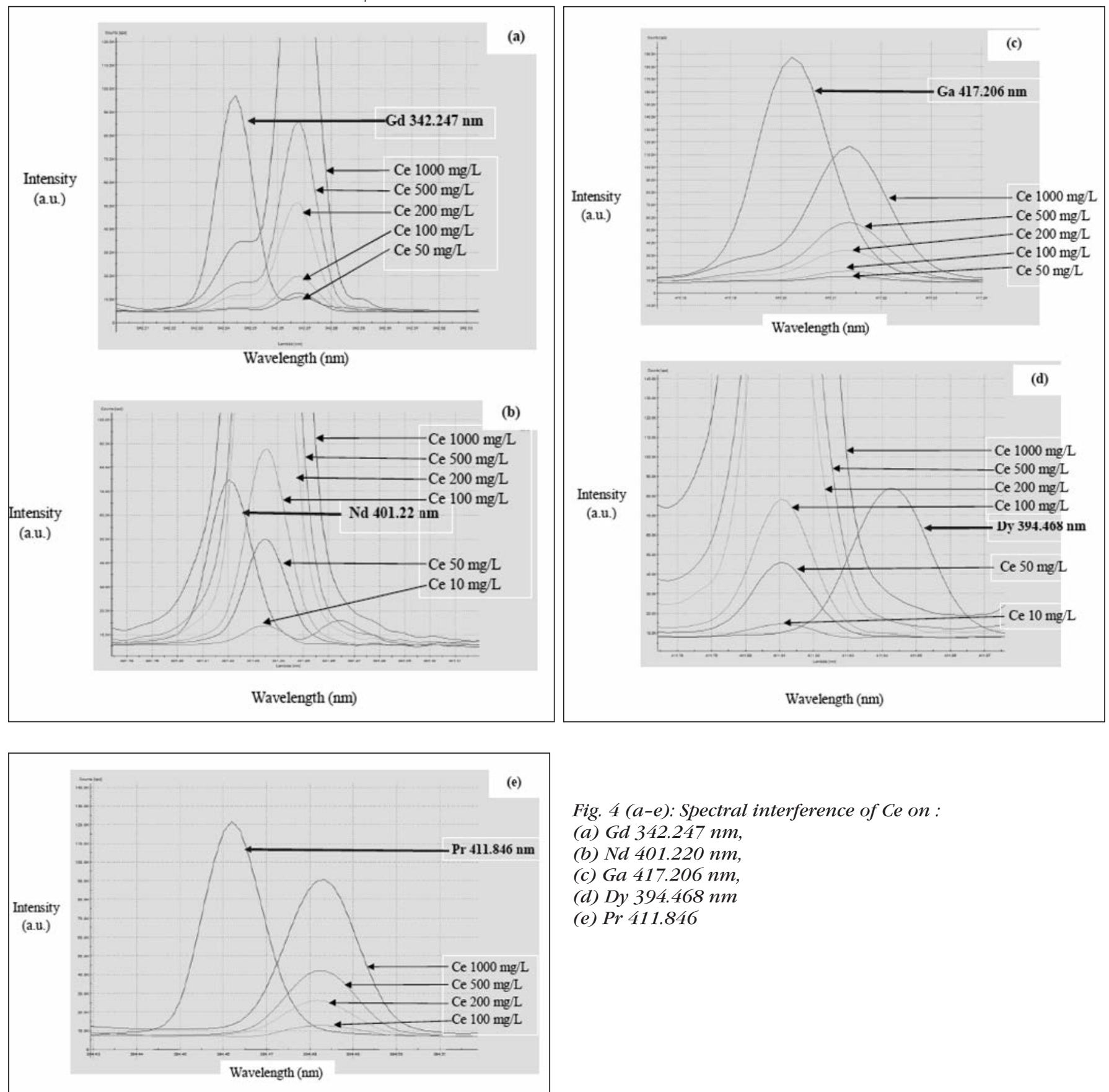

Fig. 4 (a-e): Spectral interference of Ce on:

(a) Gd $342.247 \mathrm{~nm}$,

(b) $\mathrm{Nd} 401.220 \mathrm{~nm}$,

(c) $\mathrm{Ga} 417.206 \mathrm{~nm}$,

(d) $D y 394.468 \mathrm{~nm}$

(e) $\operatorname{Pr} 411.846$ 

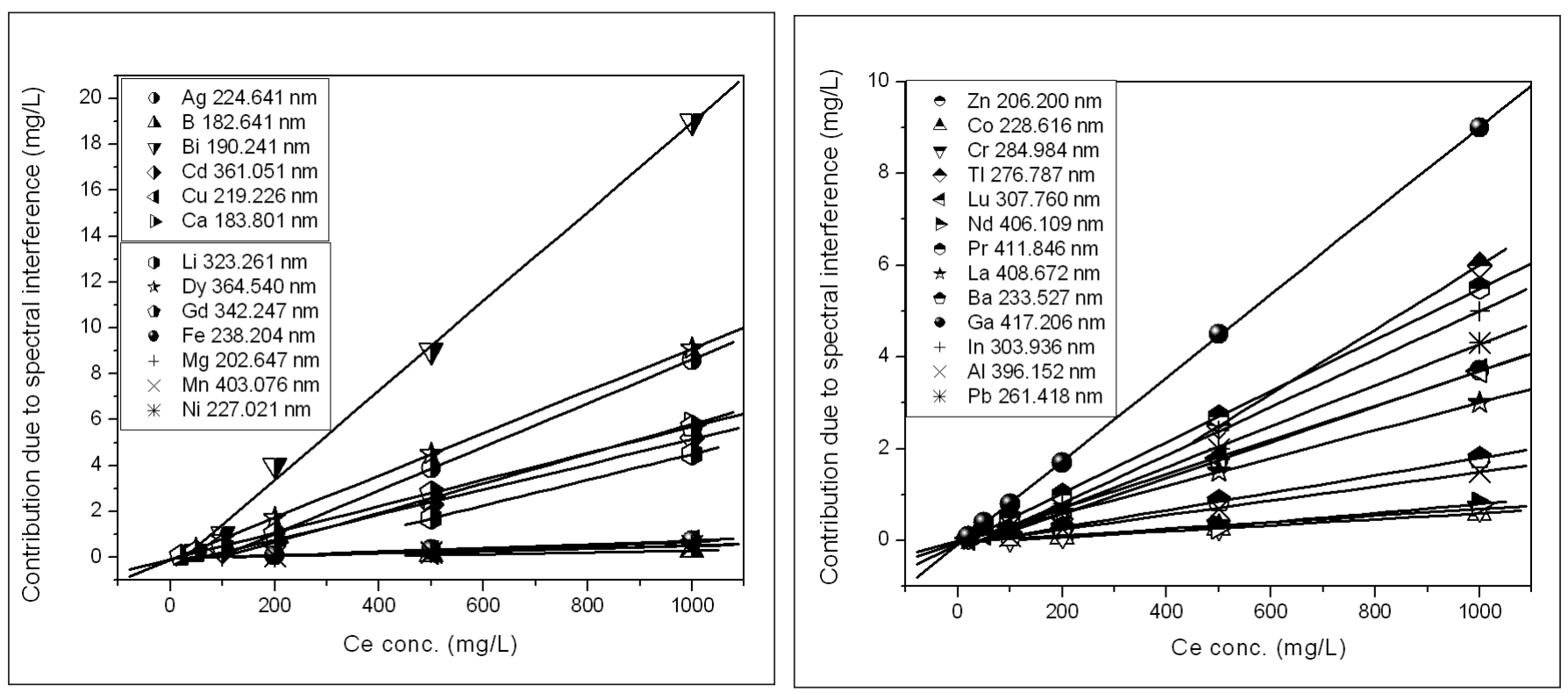

Fig. 5. Contributions on Ce on analytical lines of the elements as a function of Ce concentration.

chemical separation. The content of the six synthetic samples prepared was as follows:

1. Synthetic sample 1 (S 1): $0.1 \mathrm{mg} / \mathrm{L}$ of $\mathrm{Ag}, \mathrm{B}, \mathrm{Bi}, \mathrm{Cd}, \mathrm{Cu}, \mathrm{Ca}$, Li, Ni, Sr, Gd, Fe, Mg, Mn, Zn, and Dy in $1000 \mathrm{mg} / \mathrm{L}$ of Ce.

2. Synthetic sample 2 (S 2): $1 \mathrm{mg} / \mathrm{L}$ of $\mathrm{Ag}, \mathrm{B}, \mathrm{Bi}, \mathrm{Cd}, \mathrm{Cu}, \mathrm{Ca}, \mathrm{Li}$, $\mathrm{Ni}, \mathrm{Sr}, \mathrm{Gd}, \mathrm{Fe}, \mathrm{Mg}, \mathrm{Mn}, \mathrm{Zn}$, and Dy in $1000 \mathrm{mg} / \mathrm{L}$ of Ce.

3. Synthetic sample 3 (S 3): $0.2 \mathrm{mg} / \mathrm{L}$ of $\mathrm{Na}, \mathrm{Co}, \mathrm{Cr}, \mathrm{Tl}, \mathrm{Lu}, \mathrm{Nd}$, $\mathrm{Pr}$, and $\mathrm{La}$ in $1000 \mathrm{mg} / \mathrm{L}$ of Ce.

4. Synthetic sample 4 (S 4): $2 \mathrm{mg} / \mathrm{L}$ of $\mathrm{Na}, \mathrm{Co}, \mathrm{Cr}, \mathrm{Tl}, \mathrm{Lu}, \mathrm{Nd}, \mathrm{Pr}$, and $\mathrm{La}$ in $1000 \mathrm{mg} / \mathrm{L}$ of Ce.

5. Synthetic sample 5 (S 5): $1 \mathrm{mg} / \mathrm{L}$ of $\mathrm{Ba}, \mathrm{Ga}, \mathrm{In}, \mathrm{Al}$, and $\mathrm{Pb}$ in $1000 \mathrm{mg} / \mathrm{L}$ of Ce.

6. Synthetic sample 6 (S 6): $10 \mathrm{mg} / \mathrm{L}$ of $\mathrm{Ba}, \mathrm{Ga}$, In, $\mathrm{Al}$, and $\mathrm{Pb}$ in $1000 \mathrm{mg} / \mathrm{L}$ of Ce.

From the results it became evident that $\mathrm{Ag}, \mathrm{B}, \mathrm{Bi}, \mathrm{Cd}, \mathrm{Cu}, \mathrm{Ca}, \mathrm{Li}$, $\mathrm{Ni}, \mathrm{Sr}, \mathrm{Gd}, \mathrm{Fe}, \mathrm{Mg}, \mathrm{Mn}, \mathrm{Zn}$, and Dy can be estimated in the presence of a cerium matrix even at $0.1 \mathrm{mg} / \mathrm{L}$.
The analytes $\mathrm{Na}, \mathrm{Co}, \mathrm{Cr}, \mathrm{Tl}, \mathrm{Lu}, \mathrm{Nd}$, $\mathrm{Pr}$, and La (which were slightly interfered by Ce) can be estimated at $0.2 \mathrm{mg} / \mathrm{L}$, and $\mathrm{Ba}, \mathrm{Ga}, \mathrm{In}, \mathrm{Al}$, and $\mathrm{Pb}$ (which were significantly interfered by $\mathrm{Ce}$ ) can be estimated as low as $1 \mathrm{mg} / \mathrm{L}$ in the presence of $1000 \mathrm{mg} / \mathrm{L}$ of Ce. The analyses results of the synthetic samples are listed in Tables IX - XI.

\section{Comparison of Present Method With Other Existing Analytical Methods}

A comparison of the present methodology with existing analytical techniques was carried out and the results are listed in Table XII. The synthetic samples contained $0.5 \mathrm{mg} / \mathrm{L}$ of $\mathrm{Ag}, \mathrm{B}, \mathrm{Bi}, \mathrm{Cd}, \mathrm{Cu}, \mathrm{Ca}$, $\mathrm{Li}, \mathrm{Ni}, \mathrm{Sr}, \mathrm{Gd}, \mathrm{Fe}, \mathrm{Mg}, \mathrm{Mn}, \mathrm{Zn}$, and Dy; $1.0 \mathrm{mg} / \mathrm{L}$ concentration of $\mathrm{Co}$, Cr, La, Lu, Tl, Nd, and $\mathrm{Pr} ; 2.0$ $\mathrm{mg} / \mathrm{mL}$ of $\mathrm{Al}, \mathrm{Ba}, \mathrm{Ga}, \mathrm{In}$, and $\mathrm{Pb}$ in $1000 \mathrm{mg} / \mathrm{L}$ of Ce. The synthetic sample was directly fed to the plasma for analysis without chemical separation. The results were corrected for spectral interference of Ce using correction factors as evaluated. The analytical results thus obtained were compared with the existing analytical techniques For Ag, flame atomic absorption spectrometry was used (32); for common metallic analytes, the D.C. arc carrier distillation technique (33) was used; and for rare earth elements, ion chromatography was employed (34). The results obtained by the present method were found to compare well with the existing methods.

\section{CONCLUSION}

The systematic studies on the spectral interference of Ce on different analytes and the analytical performance of the different analytical lines of these analytes revealed that the analytical lines of Ag $328.608 \mathrm{~nm}$ and $338.289 \mathrm{~nm}$; B $208.959 \mathrm{~nm}$ and $\mathrm{Bi} 306.772 \mathrm{~nm}$; Cd $226.502 \mathrm{~nm}, \mathrm{Cu} 327.396 \mathrm{~nm}$ and $\mathrm{Cu} 324.754 \mathrm{~nm}$; Ca 317.923 nm; Li $670.780 \mathrm{~nm}$; Ni $341.476 \mathrm{~nm}$; Sr $21.552 \mathrm{~nm}$ and $\mathrm{Sr} 407.771 \mathrm{~nm}$; Gd 336.223 nm; Fe 373.486 nm; Mg 280.270 nm; Mn $257.611 \mathrm{~nm}$ and $\mathrm{Mn} 260.569 \mathrm{~nm} ; \mathrm{Zn} 213.856$ $\mathrm{nm}$; and Dy $353.602 \mathrm{~nm}$, Dy $353.170 \mathrm{~nm}$, and Dy $340.780 \mathrm{~nm}$ were not interfered by Ce. These lines also showed the best analyti- 


\section{Atomic Apectroscopy \\ $\bigcup$ Vol. 36(5), Sept./Oct. 2015}

TABLE IX

Validation of the Method Using Synthetic Samples Containing $\mathrm{Ag}, \mathrm{B}, \mathrm{Bi}, \mathrm{Cd}, \mathrm{Cu}, \mathrm{Ca}, \mathrm{Li}, \mathrm{Ni}, \mathrm{Sr}, \mathrm{Gd}, \mathrm{Fe}, \mathrm{Mg}, \mathrm{Mn}, \mathrm{Zn}$, and $\mathrm{Dy}$

\begin{tabular}{cc|cc|cc}
\hline $\begin{array}{c}\text { Ele- } \\
\text { ments }\end{array}$ & $\begin{array}{c}\text { Analytical } \\
\text { Lines } \\
(\mathrm{nm})\end{array}$ & $\begin{array}{c}\text { Actual } \\
\text { Conc. } \\
(\mathrm{mg} / \mathrm{L})\end{array}$ & $\begin{array}{c}\text { Amount Estimated } \\
\text { After Incorporating } \\
\text { Correction Factor } \\
(\mathrm{mg} / \mathrm{L})\end{array}$ & $\begin{array}{c}\text { S2 } \\
\text { Actual } \\
\text { Conc. } \\
(\mathrm{mg} / \mathrm{L})\end{array}$ & $\begin{array}{c}\text { Amount Estimated } \\
\text { After Incorporating } \\
\text { Correction Factor } \\
(\mathrm{mg} / \mathrm{L})\end{array}$ \\
\hline $\mathrm{Ag}$ & 328.068 & 0.1 & $0.092 \pm 0.003$ & 1 & $1.16 \pm 0.05$ \\
& 338.289 & 0.1 & $0.098 \pm 0.006$ & 1 & $1.08 \pm 0.09$ \\
$\mathrm{~B}$ & 208.959 & 0.1 & $0.106 \pm 0.005$ & 1 & $0.97 \pm 0.04$ \\
$\mathrm{Bi}$ & 306.772 & 0.1 & $0.108 \pm 0.006$ & 1 & $0.98 \pm 0.06$ \\
$\mathrm{Cd}$ & 226.502 & 0.1 & $0.096 \pm 0.005$ & 1 & $1.02 \pm 0.07$ \\
$\mathrm{Cu}$ & 327.396 & 0.1 & $0.097 \pm 0.004$ & 1 & $1.11 \pm 0.09$ \\
& 324.754 & 0.1 & $0.099 \pm 0.005$ & 1 & $1.06 \pm 0.05$ \\
$\mathrm{Ca}$ & 317.923 & 0.1 & $0.102 \pm 0.007$ & 1 & $0.93 \pm 0.07$ \\
$\mathrm{Li}$ & 670.78 & 0.1 & $0.093 \pm 0.008$ & 1 & $0.96 \pm 0.05$ \\
$\mathrm{Ni}$ & 341.476 & 0.1 & $0.098 \pm 0.003$ & 1 & $1.03 \pm 0.08$ \\
$\mathrm{Sr}$ & 421.552 & 0.1 & $0.106 \pm 0.007$ & 1 & $0.99 \pm 0.03$ \\
& 407.771 & 0.1 & $0.101 \pm 0.003$ & 1 & $1.09 \pm 0.09$ \\
$\mathrm{Gd}$ & 336.223 & 0.1 & $0.092 \pm 0.004$ & 1 & $1.10 \pm 0.06$ \\
$\mathrm{Fe}$ & 373.486 & 0.1 & $0.095 \pm 0.006$ & 1 & $0.98 \pm 0.06$ \\
$\mathrm{Mg}$ & 280.27 & 0.1 & $0.092 \pm 0.003$ & 1 & $0.97 \pm 0.06$ \\
$\mathrm{Mn}$ & 257.611 & 0.1 & $0.097 \pm 0.003$ & 1 & $1.01 \pm 0.05$ \\
& 260.569 & 0.1 & $0.104 \pm 0.006$ & 1 & $1.04 \pm 0.04$ \\
$\mathrm{Zn}$ & 213.856 & 0.1 & $0.108 \pm 0.003$ & 1 & $0.93 \pm 0.06$ \\
$\mathrm{Dy}$ & 353.602 & 0.1 & $0.095 \pm 0.004$ & 1 & $1.08 \pm 0.06$ \\
& 353.17 & 0.1 & $0.109 \pm 0.008$ & 1 & $1.07 \pm 0.08$ \\
& 340.78 & 0.1 & $0.092 \pm 0.007$ & 1 & $0.95 \pm 0.05$ \\
\hline & & & & & \\
\hline
\end{tabular}

cal performance and hence can be chosen for the determination of these analytes in the presence of a Ce matrix without chemical separation and without incorporation of the correction factors. The best analytical lines for the following analytes were: Co $238.892 \mathrm{~nm}$; Cr $205.618 \mathrm{~nm}$; La $333.749 \mathrm{~nm} ; \mathrm{Na}$ $589.592 \mathrm{~nm}$ and $\mathrm{Na} 588.995 \mathrm{~nm}$; Lu $261.542 \mathrm{~nm}$; T1 $190.864 \mathrm{~nm}$; Nd $430.388 \mathrm{~nm}$; Pr $422.535 \mathrm{~nm}$; Al $396.152 \mathrm{~nm}$; Ba $455.404 \mathrm{~nm}$; Ga $294.364 \mathrm{~nm} ; \mathrm{Pb} 283.305 \mathrm{~nm}$; and In $230.606 \mathrm{~nm}$ and $\mathrm{In} 325.609$ nm. A simple, rapid ICP-AES-based method was developed for the determination these 28 analytes in a Ce matrix without chemical separation. The method was validated using synthetic samples prepared from commercially available standard reference materials of the individual solutions. The method was also compared with other existing analytical techniques such as flame atomic absorption, ion chromatography, and D.C. arc distillation. The present approach appeared to be exciting, and the analytical data were found to be in good agreement.

Receved April 10, 2015.

TABLE $\mathbf{X}$

Validation of the Method using Synthetic Samples Containing Na, Co, Cr, La, Lu, Tl, Nd, and Pr

\begin{tabular}{|c|c|c|c|c|c|c|c|}
\hline $\begin{array}{l}\text { Ele- } \\
\text { ments }\end{array}$ & $\begin{array}{l}\text { Analytical } \\
\text { Lines } \\
(\mathrm{nm})\end{array}$ & $\begin{array}{l}\text { Actual } \\
\text { Conc. } \\
\text { (mg/L) }\end{array}$ & $\begin{array}{l}\text { S3 } \\
\text { Amount Estimated } \\
\text { Before Incorporating } \\
\text { Correction Factor } \\
(\mathrm{mg} / \mathrm{L})\end{array}$ & $\begin{array}{c}\text { Amount Estimated } \\
\text { After Incorporating } \\
\text { Correction Factor } \\
(\mathrm{mg} / \mathrm{L})\end{array}$ & $\begin{array}{l}\text { Actual } \\
\text { Conc. } \\
(\mathrm{mg} / \mathrm{L})\end{array}$ & $\begin{array}{c}\text { S4 } \\
\text { Amount Estimated } \\
\text { Before Incorporating } \\
\text { Correction Factor } \\
(\mathrm{mg} / \mathrm{L})\end{array}$ & $\begin{array}{l}\text { Amount Estimated } \\
\text { After Incorporating } \\
\text { Correction Factor } \\
(\mathrm{mg} / \mathrm{L})\end{array}$ \\
\hline $\mathrm{Na}$ & 589.592 & 0.2 & $0.30 \pm 0.02$ & 0.22 & 2 & $2.05 \pm 0.05$ & 1.97 \\
\hline & 588.995 & 0.2 & $0.27 \pm 0.01$ & 0.18 & 2 & $2.1 \pm 0.06$ & 2.01 \\
\hline $\mathrm{Co}$ & 238.892 & 0.2 & $0.32 \pm 0.01$ & 0.19 & 2 & $2.20 \pm 0.05$ & 2.07 \\
\hline $\mathrm{Cr}$ & 205.618 & 0.2 & $0.33 \pm 0.01$ & 0.21 & 2 & $2.08 \pm 0.03$ & 1.96 \\
\hline $\mathrm{La}$ & 333.749 & 0.2 & $0.39 \pm 0.02$ & 0.2 & 2 & $2.22 \pm 0.07$ & 2.03 \\
\hline $\mathrm{Lu}$ & 261.542 & 0.2 & $0.29 \pm 0.02$ & 0.19 & 2 & $2.15 \pm 0.07$ & 2.05 \\
\hline $\mathrm{Tl}$ & 190.864 & 0.2 & $0.53 \pm 0.03$ & 0.21 & 2 & $2.35 \pm 0.08$ & 2.03 \\
\hline $\mathrm{Nd}$ & 430.388 & 0.2 & $0.46 \pm 0.02$ & 0.22 & 2 & $2.29 \pm 0.05$ & 2.05 \\
\hline $\operatorname{Pr}$ & 422.535 & 0.2 & $0.35 \pm 0.01$ & 0.22 & 2 & $2.11 \pm 0.07$ & 1.98 \\
\hline
\end{tabular}


TABLE XI

Validation of the Method using Synthetic Samples Containing Al, Ba, Ga, In, and Pb

\begin{tabular}{|c|c|c|c|c|c|c|c|}
\hline \multirow{2}{*}{\multicolumn{2}{|c|}{$\begin{array}{lc}- & \\
\text { Ele- } & \text { Analytical } \\
\text { ments } & \text { Lines } \\
& (n m)\end{array}$}} & \multicolumn{3}{|c|}{ S5 } & \multicolumn{3}{|c|}{ s6 } \\
\hline & & $\begin{array}{l}\text { Actual } \\
\text { Conc. } \\
(\mathrm{mg} / \mathrm{L})\end{array}$ & $\begin{array}{l}\text { Amount Estimated } \\
\text { Before Incorporating } \\
\text { Correction Factor } \\
(\mathrm{mg} / \mathrm{L})\end{array}$ & $\begin{array}{l}\text { Amount Estimated } \\
\text { After Incorporating } \\
\text { Correction Factor } \\
(\mathrm{mg} / \mathrm{L})\end{array}$ & $\begin{array}{l}\text { Actual } \\
\text { Conc. } \\
(\mathrm{mg} / \mathrm{L})\end{array}$ & $\begin{array}{c}\text { Amount Estimated } \\
\text { Before Incorporating } \\
\text { Correction Factor } \\
(\mathrm{mg} / \mathrm{L})\end{array}$ & $\begin{array}{c}\text { Amount Estimated } \\
\text { After Incorporating } \\
\text { Correction Factor } \\
(\mathrm{mg} / \mathrm{L})\end{array}$ \\
\hline $\mathrm{Al}$ & 396.152 & 1 & $2.70 \pm 0.05$ & 1.2 & 5 & $6.46 \pm 0.06$ & 4.96 \\
\hline $\mathrm{Ba}$ & 455.404 & 1 & $2.19 \pm 0.08$ & 0.89 & 5 & $6.35 \pm 0.08$ & 5.05 \\
\hline $\mathrm{Ga}$ & 294.364 & 1 & $4.70 \pm 0.06$ & 0.9 & 5 & 9.000 .08 & 5.2 \\
\hline In & 230.606 & 1 & $1.90 \pm 0.07$ & 1.06 & 5 & $5.94 \pm 0.09$ & 5.1 \\
\hline & 325.609 & 1 & $1.71 \pm 0.06$ & 1.02 & 5 & $5.75 \pm 0.09$ & 5.06 \\
\hline $\mathrm{Pb}$ & 283.305 & 1 & $1.44 \pm 0.05$ & 0.97 & 5 & $5.52 \pm 0.07$ & 5.05 \\
\hline
\end{tabular}

TABLE XII

Comparison of the Present Methodology with Existing Analytical Techniques

\begin{tabular}{|c|c|c|c|c|c|c|c|}
\hline $\begin{array}{l}\text { Ele- } \\
\text { ments }\end{array}$ & $\begin{array}{l}\text { Analytical } \\
\text { Lines } \\
\text { (nm) }\end{array}$ & $\begin{array}{l}\text { Estimated by } \\
\text { Present Method } \\
(\mathrm{mg} / \mathrm{L})\end{array}$ & $\begin{array}{c}\text { Comparison With } \\
\text { Other Method } \\
(\mathrm{mg} / \mathrm{L})\end{array}$ & $\begin{array}{c}\text { Ele- } \\
\text { ments }\end{array}$ & $\begin{array}{l}\text { Analytical } \\
\text { Lines } \\
(\mathrm{nm})\end{array}$ & $\begin{array}{l}\text { Estimated by } \\
\text { Present Method } \\
(\mathrm{mg} / \mathrm{L})\end{array}$ & $\begin{array}{c}\text { Comparison With } \\
\text { Other Method } \\
(\mathrm{mg} / \mathrm{L})\end{array}$ \\
\hline \multirow[t]{2}{*}{ Ag } & 328.068 & $0.51 \pm 0.03$ & $0.49 \pm 0.02^{\mathrm{a}}$ & \multirow[t]{3}{*}{ Dy } & 353.602 & $0.49 \pm 0.03$ & $0.51 \pm 0.04^{\mathrm{c}}$ \\
\hline & 338.289 & $0.47 \pm 0.02$ & $0.46 \pm 0.04^{\mathrm{a}}$ & & 353.17 & $0.51 \pm 0.05$ & $0.48 \pm 0.04^{\mathrm{c}}$ \\
\hline B & 208.959 & $0.50 \pm 0.03$ & $0.48 \pm 0.04^{\mathrm{b}}$ & & 340.78 & $0.50 \pm 0.04$ & $0.48 \pm 0.04^{\mathrm{c}}$ \\
\hline $\mathrm{Bi}$ & 306.772 & $0.49 \pm 0.01$ & $0.51 \pm 0.03^{\mathrm{b}}$ & \multirow[t]{2}{*}{$\mathrm{Na}$} & 589.592 & $1.15 \pm 0.08$ & $0.98 \pm 0.07^{\mathrm{b}}$ \\
\hline $\mathrm{Cd}$ & 226.502 & $0.51 \pm 0.04$ & $0.50 \pm 0.04^{\mathrm{b}}$ & & 588.995 & $1.05 \pm 0.07$ & $1.13 \pm 0.07^{\mathrm{b}}$ \\
\hline \multirow[t]{2}{*}{$\mathrm{Cu}$} & 327.396 & $0.48 \pm 0.02$ & $0.51 \pm 0.05^{\mathrm{b}}$ & Co & 238.892 & $0.98 \pm 0.08$ & $1.05 \pm 0.08^{\mathrm{b}}$ \\
\hline & 324.754 & $0.49 \pm 0.04$ & $0.47 \pm 0.03^{\mathrm{b}}$ & $\mathrm{Cr}$ & 205.618 & $1.10 \pm 0.06$ & $1.08 \pm 0.07^{\mathrm{b}}$ \\
\hline $\mathrm{Ca}$ & 317.923 & $0.51 \pm 0.04$ & $0.49 \pm 0.03^{\mathrm{b}}$ & $\mathrm{La}$ & 333.749 & $0.97 \pm 0.06$ & $0.96 \pm 0.07^{c}$ \\
\hline $\mathrm{Li}$ & 670.78 & $0.50 \pm 0.02$ & $0.51 \pm 0.04^{\mathrm{b}}$ & $\mathrm{Lu}$ & 261.542 & $0.99 \pm 0.05$ & $0.97 \pm 0.08^{\mathrm{c}}$ \\
\hline $\mathrm{Ni}$ & 341.476 & $0.47 \pm 0.04$ & $0.51 \pm 0.03_{\mathrm{b}}$ & $\mathrm{Tl}$ & 190.864 & $1.08 \pm 0.07$ & $0.98 \pm 0.08^{b}$ \\
\hline \multirow[t]{2}{*}{$\mathrm{Sr}$} & 421.552 & $0.47 \pm 0.02$ & $0.50 \pm 0.03^{\mathrm{b}}$ & $\mathrm{Nd}$ & 430.388 & $1.11 \pm 0.09$ & $1.01 \pm 0.07^{\mathrm{c}}$ \\
\hline & 407.771 & $0.49 \pm 0.05$ & $0.46 \pm 0.05^{b}$ & $\operatorname{Pr}$ & 422.535 & $0.97 \pm 0.08$ & $1.06 \pm 0.08^{c}$ \\
\hline Gd & 336.223 & $0.51 \pm 0.02$ & $0.47 \pm 0.04^{\mathrm{c}}$ & $\mathrm{Al}$ & 396.152 & $2.10 \pm 0.09$ & $2.05 \pm 0.08^{\mathrm{b}}$ \\
\hline $\mathrm{Fe}$ & 373.486 & $0.50 \pm 0.05$ & $0.48 \pm 0.04^{\mathrm{b}}$ & $\mathrm{Ba}$ & 455.404 & $1.97 \pm 0.08$ & $2.11 \pm 0.07^{\mathrm{b}}$ \\
\hline $\mathrm{Mg}$ & 280.27 & $0.50 \pm 0.02$ & $0.48 \pm 0.04^{\mathrm{b}}$ & Ga & 294.364 & $2.05 \pm 0.07$ & $1.95 \pm 0.07^{\mathrm{b}}$ \\
\hline \multirow[t]{2}{*}{ Mn } & 257.611 & $0.49 \pm 0.02$ & $0.51 \pm 0.04^{\mathrm{b}}$ & In & 230.606 & $1.98 \pm 0.06$ & $1.94 \pm 0.07^{\mathrm{b}}$ \\
\hline & 260.569 & $0.47 \pm 0.03$ & $0.50 \pm 0.03^{b}$ & & 325.609 & $1.99 \pm 0.08$ & $1.92 \pm 0.08^{\mathrm{b}}$ \\
\hline $\mathrm{Zn}$ & 213.856 & $0.48 \pm 0.04$ & $0.46 \pm 0.04^{\mathrm{b}}$ & $\mathrm{Pb}$ & 283.305 & $2.01 \pm 0.08$ & $2.11 \pm 0.07^{\mathrm{b}}$ \\
\hline
\end{tabular}

Note: The Ce concentration in the synthetic sample is $1000 \mathrm{mg} / \mathrm{L}$.

${ }^{a}=$ refers to the analysis by atomic absorption apectroscopy.

${ }^{b}=$ refers to the analysis by D.C. arc carrier distillation technique.

${ }^{c}=$ refers to the analysis by chromatographic technique. 


\section{A $_{\text {Somic }}^{\text {tomectroscopy }}$}

\section{REFERENCES}

1. S. Greenfield, I.LI. Jones, and C.T. Berry, Analyst 89, 713 (1964).

2. R.H. Wendt and V.A. Fassel, Anal. Chem. 37, 920 (1965).

3. H. Ishii and K. Satoh, Talanta 29, 243 (1982)

4. M. I. Rucandio, Fresenius J. Anal. Chem. 357, 661 (1997).

5. S. Greenfield, M. S. Salman, and J. F. Tyson, Spectrochim. Acta B 43, 1087 (1988).

6. Luís Cláudio de Oliveira1, Ieda de Souza Silva, and M Isabel Rucandio, International Nuclear Atlantic Conference, 41 (2009), ISBN: 97885-99141-03-8.

7. V.A. Fassel and R.N. Kniseley, Anal. Chem. 46, 1110A (1974).

8. P.W.J.M. Bouman's and J.J.A.M. Vrakking, Spectrochim. Acta B 39, 1239 (1984).

9. J. P.Robin, Pro. Anal. At. Spectrosc. 5, 79 (1982).

10. M. H. Abdallah, J. M. Mermet, and C. Trassy, Anal. Chim. Acta 87, 329 (1976)

11. A. Mazzucotellit, F. De Paz, E. Magi, and R. Frache, Anal. Sci. 8, 189 (1992)

12. M. I. Rucandio, Estudio sobre la aplicación de la espectroscopía de emisión con fuente de plasma acoplado por inducción a la determinación de tierras raras, Ph.D Thesis, Universidad Autónoma de Madrid, CIEMAT, Madrid, Spain, pp. 280 (1993).

13. M. I. Rucandio, Anal. Chim. Acta 264, 333 (1992)

14. L. Darbha, and S. Gangadharam, Fresenius J. Anal. Chem. 348, 284 (1994).

15. N.E. Topp, The Chemistry of Rare Earth Element. Elsevier, NY, USA (1965).

16. T. Kano, and H. Yanagida, Rare Earths: Properties and Applications, Gihado, Tokyo, Japan (1980).

17. J.H. Jolly, Rare Earth Elements and Yttrium; Mineral facts and Problems, Bureau of Mines, U.S. Depart- ment of the Interior, Washington, DC (1975).

18. J. Colon, L. Herrera, J. Smith, S. Patil, C. Komanski, P. Kupelian, S. Seal, D. W. Jenkins, and C.H Baker, Nanomedicine: Nanotechnol. Bio. Med. 5, 225 (2009).

19. S. Das, J. M Dowding, K. E. Klump, J. F. McGinnis, W. Self, and S. Seal, Nanomed. 9, 1483 (2013).

20. K. Nikolaou, Sci. Total Environ. 235, 71 (1999).

21. T.X. Sayle, S.C. Parker, and D C. Sayle, Phys. Chem. Chem. Phys. 7 , 2936 (2005).

22. M. Sugiura, Catal. Surv. Asia 7, 77 (2003).

23. J. G. Teeguarden, P. M. Hinderliter, G. Orr, B. D. Thrall, and J. G. Pounds, Toxicol. Sci. 95, 300 (2007).

24. S. F. Marsh, Anal. Chem. 39, 641 (1967).

25. J. J. Mccown, and R P. Larsen, Anal. Chem. 33, 1003 (1961).

26. A. Masuda, N. Nakamura, and T. Tanaka, Geochim. Cosmochim. Acta 37, 239 (1973).

27. P.W.J.M. Boumans, Spectrochim. Acta B 438, 173 (1988).

28. A. Mazzucotelli, F. de Paz, E. Magi, and R. Frache, Anal. Sci. 8, 189 (1992).

29. E. Kostadinova, L. Aleksieva, S. Velichkov, and N. Daskalova, Spectrochim. Acta B, 55, 689 (2000).

30. K-S Choi, C-H Lee, J-G Kim, W-H Kim, and J-G Kang, Talanta 71 , 662 (2007).

31. S. Gu, H. Ying, Z Zhang, Z. Zhuang, P. Yang, $X$. Wang, B. Huang, and L. Bing, Spectrochim. Acta B 52, 1567 (1997).

32. T. Blazheva and A. DelijskaKrushevska, Fresenius J. Anal. Chem, 338, 294 (1990).

33. N. Pathak, V.C. Adya, S.K. Thulasidas, A. Sengupta, T.K. Seshagiri, and S.V. Godbole, At. Spectrosc. 35, 17 (2014).

34. M.C.Bruzzoniti, E. Mentasti, C. Sarzanini, M. Braglia, and G. Cocito, and J. Kraus, Anal. Chim. Acta 332, 49 (1996). 